\title{
HOW PEACE SAVES LIVES: EVIDENCE FROM COLOMBIA
}

\author{
SERGIO PERILLA ${ }^{\dagger}$, MOUNU PREM ${ }^{\ddagger}$, MIGUEL E. PURROY* ${ }^{*}$ AND JUAN F. VARGAS*
}

\begin{abstract}
The victimization of civilians and combatants during internal conflicts causes large socioeconomic costs. Unfortunately, it is not clear whether peace negotiations can significantly reduce this burden. One key reason is the lingering presence of antipersonnel landmines, which are hidden underground and remain active for decades. Looking at the recent experience of Colombia, we quantify the number of lives saved by the reduction of landmine accidents and study the institutional conditions under which peace agreements can significantly reduce landmine victimization. Our findings highlight the importance of: reduced counterinsurgency campaigns, post-conflict information sharing, comprehensive humanitarian mine clearance, and mine risk management campaigns.
\end{abstract}

Keywords: Landmine accidents, landmine victimization, conflict, peace agreement. JEL codes: D74, P48, Q56, I25.

Date: March 8, 2023.

We thank Tatyana Deryugina, Charu Prem, and Julian Reif for helpful comments and suggestions. Prem and Vargas received funding from the Colombia Científica-Alianza EFI Research Program 60185 and contract No. FP44842-220-2018.

${ }^{\dagger}$ Department of Economics, Universidad del Rosario. email: sergios.perilla@urosario.edu.co.

${ }^{\ddagger}$ Einaudi Institute for Economics and Finance. email: francisco.munoz@eief.it.

${ }^{*}$ Harvard Kennedy School. email: mpurroy@hks.harvard.edu.

${ }^{\star}$ Department of Economics, Universidad del Rosario. email: juan.vargas@urosario.edu.co. 


\section{INTRODUCTION}

A vast literature highlights how violent conflicts engender large economic and social costs, thwarting long-term development. ${ }^{1}$ One troubling yet ubiquitous feature of conflict is the victimization of non-combatants.Civilian targeting in civil war is, most of the time, a deliberate strategy of armed actors (e.g., Eck and Hultman, 2007), especially in the context of territorial contestation (e.g., Kalyvas, 2006, Gibilisco et al., 2022). Supplementary to the human tragedy, this phenomenon adds to the long-term economic cost of conflict as it erodes the labor force and undermines the social tissue. ${ }^{2}$ Besides, conflicts often encompass a more silent and also indiscriminate victimization, namely that inflicted by active underground explosives such as antipersonnel landmines or unexploded ordnance (UXO). While the former were banned in 1997 by the Ottawa Convention, about 110 million such explosives prevail today in 60 countries, causing on average 26,000 victims per year and threatening the lives of millions. ${ }^{3}$ A recent example of this tragedy is the Ukraine war, where Russian troops have left behind substantial amounts of illegal underground explosives. $^{4}$

In the face of this, a pressing question is how to stop the human suffering associated with the presence antipersonnel landmines and UXO. This paper suggests that ending ongoing conflicts is an important first step, but it is not enough. The institutional conditions under which conflict termination occurs are key. We explore these issues by studying how Colombia's peace process affected landmine victimization and by quantifying the economic value of the social gain coming from the saved lives. Most importantly, we examine the extent to which ex-combatant collaboration as well as active policies aimed at reducing the risk of landmine victimization can save more lives.

\footnotetext{
${ }^{1}$ See, e.g., Blattman and Miguel (2010), Ray and Esteban (2017) for comprehensive reviews.

${ }^{2}$ For example, de Groot et al. (2022) suggests that in the absence of conflict, the global GDP since 1970 would have been $12 \%$ higher.

${ }^{3}$ See https://rb.gy/fpyk05 (last accessed 5/12/2022).

${ }^{4}$ The current landmine crisis in Ukraine has been reported, among others, by the United Nations Office for the Coordination of Humanitarian Affairs (OCHA) and by Human Rights Watch (see, e.g. https: //rb.gy/ujkcar and https://rb.gy/nklsel) (last accessed 28/11/2022).
} 
Colombia is a relevant setting to study the dynamics of landmine victimization. In 2008, the Revolutionary Armed Forces of Colombia (FARC from the Spanish acronym) -the largest and oldest insurgency in the Western Hemisphere-instigated all the organization's fronts to significantly scale up the ongoing fabrication and planting of landmines as a strategy to counteract the pressure of the Colombian Army. As a result, rural Colombia was quickly covered with improvised landmines. Today, it is the country with the highest number of victims of "improvised," homemade landmines, and that with the second largest victimization from all types of antipersonnel landmines after Afghanistan.

We identify the effect of the start of peace negotiations between Colombia's government and FARC on landmine accidents and victimization through a difference-in-differences regression model that exploits both the timing of the peace process and the previous exposure to FARC's violence. ${ }^{5}$ Peace talks were formally launched in Olso on October 18 of 2012, after eight months of secret exploratory negotiations. On that day, delegates of FARC and the Colombian government issued a press release that revealed the agreed agenda of the peace talks and highlighted their commitment not to abandon the table until reaching a peace agreement. ${ }^{6}$ The final agreement was signed on November 24, 2016. While FARC was the largest and oldest insurgency in Colombia, this however did not mark the end of the Colombian conflict, as several other groups that did not participate of the negotiations persisted after the agreement was reached. Indeed, the agreement with FARC can be rationalized as achieving only partial peace (Prem et al., 2022b).

We estimate that the start of peace negotiations triggered a differential 39 percent reduction in landmine explosions and a 45 percent reduction in the number of landmine victims

\footnotetext{
${ }^{5}$ We use a similar identification strategy to study the effects of Colombia's peace agreement of educational outcomes (Prem et al., 2021b), fertility (Guerra-Cújar et al., 2021), and entrepreneurship (Bernal et al., 2022). Importantly, however, the temporal variation is different in this paper since landmine victimization responds to a substantively different set of incentives as those exploited in the cited research.

${ }^{6}$ The public speeches of FARC commander Iván Marquez and the government chief negotiator Humberto de la Calle can be found, in their original Spanish version, here: https://rb.gy/zxpr56 (last accessed 28/11/2022).
} 
in municipalities previously exposed to FARC's violence relative to the rest of the country. This corresponds to an average of 323 lives saved each year between 2013 and 2019 which yield annual savings of over $\$ 200$ million. This average hides important temporal dynamics. For instance, after the peace agreement was signed in mid-2016, landmine victimization almost completely disappeared in areas formerly affected by FARC. It also hides key heterogeneity in terms of both victim characteristics and the type of investments received by different municipalities after the start of the peace talks.

Our empirical model includes municipal-specific and department-year fixed effects, as well as non-linear trends parametrized by pre-negotiation municipality characteristics. We also study a dynamic version of this model as well as a battery of parametric and recently proposed non-parametric tests to show that the main assumption behind the research design, namely that in the absence of the peace negotiations, landmine accidents and victims would have evolved in the same fashion in FARC-affected and other areas, is likely to hold.

We find our results to be robust to a range of different sensitivity exercises. Importantly, the validity of our empirical strategy relies on the fact that municipalities not affected by FARC also experienced violence and in some cases landmine explosions, since Colombia's conflict has traditionally featured various illegal armed groups. While for the baseline results, we use all the residual municipalities (not affected by FARC's violence) our results are robust to a battery of alternative comparison groups, including truncating the control sample based on the distribution of the propensity score in order to increase overlap in pre-treatment characteristics, implementing a synthetic difference-in-differences estimator, using only municipalities previously affected by violence from any armed group, weighting the observations by the propensity score of exposure to FARC violence, and including controls in a doubly-robust way.

We explore potential mechanisms that can account for the large reduction in landmine 
victimization following the start of the peace process in Colombia. First, we show that the military initiative of the armed forces differentially dropped in FARC-exposed areas after the start of the peace negotiations. Second, we show both quantitative and anecdotal evidence that ex-combatants collaborated with government officials and the international community to provide intel about the potential location of landmine fields. For instance, we find that the reduction in landmine accidents is over 50 percent larger in areas where former FARC combatants settled following the signature of the peace agreement. Third, we explore the role of active efforts to locate and remove landmines, as well as that of education programs to provide affected communities with mine risk management capabilities. We find that the baseline effect is substantially larger in areas that experienced any humanitarian demining campaign or any Mine Risk Education (MRE) programs. ${ }^{7}$ By comparing the economic value of the lives saved in places exposed to these either humanitarian demining or MRE with the cost of each social investment, we estimate substantial cost-benefit ratios. Fourth, we find that the drop in the number of landmine blasts is higher in magnitude in areas that are suitable to grow illegal crops, which are usually protected by landmines and thus make it easier to locate mined fields when demining opportunities arise. Taken together, these findings suggest that the de facto end of a conflict can facilitate the coordination of efforts to reduce the threat that landmines pose, and that the post-conflict reduction in victimization depends on how the different stakeholders seize these opportunities. These findings have important policy implications on how to effectively save lives in a post-conflict setting.

In turn, our findings are not driven by an overall security improvement following the start of the peace negotiations. While we show that the number of homicides did decrease differentially in former FARC-affected areas, the magnitude of this reduction is just a third of the one estimated for landmine victimization. Moreover, and in contrast to the case of

\footnotetext{
${ }^{7}$ Humanitarian demining refers to the thorough efforts of local and international non-governmental organizations (NGOs) to locate minefields and work with the support of local communities to remove all the existing landmines until the area can confidently be called mine-free. MRE are standardized pedagogic programs that seek to promote a culture of safe behaviors to avoid landmine accidents.
} 
landmine explosions, we find that the drop in the number of homicides is not affected by any of the institutional factors that do exacerbate the reduction of landmine victims.

This paper contributes to different strands of the literature. First, it focuses on a very important but relatively understudied phenomenon that is common to most internal armed conflicts: the prevalence of anti-personnel landmines and UXO. Conflicts are socially and economically costly and ground explosives contribute substantially to these costs. Conversely, comprehensive demining campaigns have been shown to entail large economic and social returns (Chiovelli et al., 2019; Prem et al., 2022a; Vargas et al., 2022). Second, it contributes to the literature that points out how successful state-building efforts need to involve different sets of institutions and guarantee enough checks and balances to avoid unintended negative consequences (see Fergusson, 2019 for a recent review). Moreover, it provides evidence for a potential mechanism behind the documented positive attitudes towards a peace-negotiation in areas that had been more affected by conflict (Tellez, 2019a, Tellez, 2019b, Pulido et al., 2019). Relatedly, a growing literature has identified how US-led areal bombing campaigns during the 1970s generated long-term negative consequences only to the extent that bombed states lacked the capacity to invest in the recovery of the affected areas (Miguel and Roland, 2011; Dell and Querubin, 2018; Riaño and Valencia Caicedo, 2020; Lin, 2020). Finally, it expands the literature on the peace dividend, and in particular on that of the intended and unintended consequences of peace agreements, including Colombia's (Prem et al., 2020, 2022b, 2021a,b; Guerra-Cújar et al., 2021; de Roux and Martinez, 2021; Bernal et al., 2022).

\section{Context}

The start of the most recent internal armed conflict in Colombia dates back to the 1960s, when FARC and another large left-wing guerrilla (the National Liberation Army, ELN from its Spanish acronym) were founded. Other smaller insurgencies appeared later, and 
so did right-wing paramilitary groups -originally armed by the state in the early 1970s and trained as self-defense organizations. Both the guerrillas and the paramilitary groups commonly victimize civilians as a means of achieving territorial control. This is a common strategy in civil wars (Kalyvas, 2006; Vargas, 2016; Prem et al., 2022b; Gibilisco et al., 2022). ${ }^{8}$

Landmines have extensively been used in Colombia as a way to secure the strongholds and illegal crops of the guerrillas. In fact, Colombia is the country with the highest number of victims of improvised anti-personnel mines. Over 12,000 Colombians have been directly affected by such artifacts since $1999 .{ }^{9}$ The peak in the fabrication and planting of improvised mines in Colombia came in 2008, when FARC's secretariat launched a strategy that they called Plan Renacer Revolucionario de las Masas (Revolutionary Rebirth of the Masses). In an internal secret memorandum, commander 'Alfonso Cano' instigated all fronts to strengthen their guerrilla warfare tactics to regain territory as well as protect their strongholds. To that end, Cano encouraged the troops to take courses on making and planting mines. ${ }^{10}$

In October 2012, the Colombian government and FARC started peace negotiations in Cuba. This marked the start of a new and more peaceful equilibrium in the long history of the Colombian conflict. As an illustration of this, Figure A2 shows how several variables related to the incidence of conflict have substantially decreased since the beginning of the peace negotiations. Humanitarian demining efforts also started to pick up soon after the start of peace negotiations. Decree 3570 of 2011 established that any national or

\footnotetext{
${ }^{8}$ Today over 9 million people are registered as victims of the Colombian conflict. Source: Victims' Registry, from the Unit for the Victims Assistance and Reparation, June 2021 figure. Available from: https://www. unidadvictimas.gov.co/ (last accessed 12/12/2022).

${ }^{9}$ Improvised landmines are homemade explosives that detonate by contact or even in the proximity of a person or object. They are harder to detect and remove without risking an explosion (Landmine Monitor, 2019).

${ }^{10} \mathrm{~A}$ copy of the memo in the original Spanish can be found in Appendix Figure A1. While the extent of the contamination with mines is highly uncertain, by the end of last decade at least $88 \%$ of Colombian departments (equivalent to U.S. states) were suspected of hosting landmines, and the area contaminated with landmines was officially estimated to be around 11,400 acres (Landmine Monitor, 2017), equivalent to $78 \%$ of the size of Manhattan.
} 
foreign NGOs could undertake humanitarian demining, and the first NGO that engaged in demining activity was Halo Trust.

The final agreement was signed on November 24, 2016. Importantly, however, several of the smaller illegal armed groups that marked the dynamics of the Colombian conflict persisted afterwards. Thus, the peace reached after the agreement with FARC did not mark the end of the internal conflict (Prem et al., 2022b).

\section{THEORETICAL FRAMEWORK}

We argue that the end of conflict is a necessary but perhaps not sufficient condition for reducing landmine victimization in conflict-affected countries that host these types of explosives. This is mainly because landmines remain active for decades, regardless of the end of hostilities. Hence, the institutional conditions under which conflict termination occurs are fundamental to achieve important and persistent gains in this form of victimization, that is prevalent across dozens of countries and produces thousands of casualties.

In this section, we highlight a few hypotheses that relate conflict termination with landmine victimization, depending on key institutional factors. We start by noticing that conflict can end because of a range of reasons, from outright military victory to a negotiated peace agreement (Kreutz, 2010). In the latter case, de-escalation measures are commonly introduced, even during the negotiation period. These include ceasefires and mandates to disengage from practices such as kidnappings, bombardments, child soldiering, or the utilization of certain types of warfare artifacts.

In turn, de-escalation can mechanically reduce landmine victimization. For instance, as the Colombian military reduced its ground offensive during the peace negotiations (especially after the permanent ceasefire was declared), the incentive to plant new landmines to protect strongholds faded, and so did the probability of triggering existing explosives. This implies that de-escalation initiatives - on the verge or in the aftermath of peace 
treaties-will most likely reduce landmine victimization in the areas affected by such explosives. This leads us to a first hypothesis:

H1: Places affected by conflict and hosting landmines will experience a decrease in landmine victimization after episodes of conflict de-escalation (such as peace negotiations or ceasefires).

Moreover, the nature of peace negotiations encourages the involved parties to implement confidence-building measures (Mason and Siegfried, 2013). This helps them been seen as trustworthy negotiators, which ultimately feeds into the probability of success of the bargaining process. Groups involved in the negotiations have therefore incentives to comply to initial provisions and to partial agreements, suggesting that the reduction in victimization is likely to be exacerbated over time. This leads us to the second hypothesis:

H2: When peace negotiations are successfully carried out uninterruptedly, the reduction in landmine victimization in places affected by conflict will be increasing over time.

We also posit that institutional conditions play a crucial role in fostering a reduction in victimization. For instance, an important aspect of peace negotiations is the sharing of information between the rebels and the government. Given the nature of landmines and specifically their unknown location, detecting and removing them is a challenging task. Thus, collaboration between illegal armed groups, the government, and the civilian population is essential in further reducing the burden of these artifacts. Based on this discussion we hypothesize:

H3: The reduction in landmine victimization is larger in places where there is informational exchange about the location of mine fields.

Another critical aspect of peace negotiations in landmine-affected areas is the implementation of policies to reduce the risks associated with their presence. Such policies usually come in two forms: humanitarian demining campaigns and Mine Risk Education (MRE) 
programs. The former aim to clear entire mine fields with the collaboration of local communities and are a crucial component of post-conflict investments (Chiovelli et al., 2019; Prem et al., 2022a). The collaboration between the government and illegal armed groups allows NGOs to enter closer to strongholds to perform demining tasks, which helps protecting civilians from landmines accidents. In addition to demining campaigns, MRE programs promote safe behaviors and best practices among civilians living in landmineaffected areas. Communities with greater exposure to these policies are expected to experience more significant reductions in victimization. We conjecture:

H4: The reduction in landmine victimization is larger in places more exposed to landminerelated post-conflict investments.

Before moving to the data section and empirical design, it is essential to highlight that the magnitude of the coefficients is as crucial as their sign and statistical significance to contrast the aforementioned hypotheses. By considering the size of the coefficients, we intend to perform a cost-benefit analysis to determine the net gains in terms of the statistical value of the lives saved, compared to the costs of different post-conflict investments. Such an analysis likely provides valuable insights into future post-conflict investment decisions in similar contexts.

\section{DATA}

4.1. Landmine explosions and victims. Colombia is one of the 164 nations that subscribed to the Ottawa Convention, which forbids the employment, storage, production, and transfer of anti-personnel mines. As part of the commitments adopted from the Convention, Colombia started an official periodic registry of landmine explosions, suspicion of presence, and demining events. To this end, the country adopted the Information Management System for Mine Action (IMSMA) of the Geneva International Centre for Humanitarian Demining (GICHD). ${ }^{11}$ IMSMA provides geo-located data on all landmine

\footnotetext{
${ }^{11}$ See https://rb.gy/m2zzom (last accessed 28/11/2022). Colombia's current commitment is to clear landmines from the entire territory by 2025 .
} 
explosion events since 1990. Each explosion event contains a brief description of the accident including the location and date of the detonation, the alleged party responsible for placing the landmine, and information about the resulting victims (e.g. the victim's gender, age, whether they are civilian or a member of the armed forces, and the type of victimization -injury or death). From these data, we define our main outcomes (the total number of landmine explosions and the total number of victims), which we aggregate to the municipality-year level over the period $1990-2019 .{ }^{12}$ Figure 1 reports the spatial distribution of the change in landmine victims before and after the beginning of the peace negotiation. Darker grey shades represent larger drops in landmine victims.

4.2. Conflict. To construct our measure of exposure to FARC violence prior to the start of the peace negotiations, we use the conflict dataset originally compiled by Restrepo et al. (2004) and updated through 2019 by Universidad del Rosario. We describe these data, which have been extensively used to study the Colombian conflict, in Appendix A1. Our main measure of exposure to FARC violence is an indicator that takes the value one for municipalities that experienced a FARC violent event during the two years prior to the start of the peace negotiations: 2011 and 2012. ${ }^{13}$ Our results are robust to using a range of additional treatment definitions, including one that defines exposure over the period that coincides with the launch of Plan Renacer (see section 6.2). The red dots in Figure 1 show the spatial distribution of FARC violence prior to the start of the peace negotiation. These tend to be present in darker municipalities, visually suggesting that the drop in victimization was larger in municipalities exposed to FARC violence.

We use a range of additional variables as controls as well as to test potential mechanisms. We describe these, together with their source, in Appendix A1.

\footnotetext{
${ }^{12}$ Appendix Table A1 provides some basic statistics about landmines explosions and victimization by type of casualty.

${ }^{13} 2011$ is the first year since president Juan Manuel Santos was elected.
} 


\section{EMPIRICAL STRATEGY}

To study the role that the peace negotiation had on landmine explosions and victims, we exploit the temporal variation given by the beginning of the peace negotiation between the Colombian government and FARC, as well as the cross-sectional variation given the prior exposure to FARC violence of municipalities. More formally, using the sub-index $m$ to denote municipalities, $d$ to denote departments, and $t$ to denote time, we estimate the following difference-in-differences model: ${ }^{14}$

$$
y_{m d t}=\alpha_{m}+\lambda_{d t}+\beta \times\left(\text { Negotiation }_{t} \times F A R C_{m}\right)+\sum_{c \in \mathbf{X}_{\mathbf{m}}} \gamma^{\prime}\left(c \times \delta_{t}\right)+\varepsilon,,_{m d t}
$$

where $y_{m d t}$ are different measures of victims and landmine explosions, $F A R C_{m}$ is a dummy that takes the value one if there was any violent attack perpetrated by FARC in municipality $m$ between 2011 and 2012, and Negotiation is a dummy that takes the value one after the start beginning of the peace negotiation, from 2013 onward. $\alpha_{m}$ are municipality fixed effects and $\lambda_{d t}$ are department-year fixed effects. These set of fixed effects control respectively for any observed or unobserved municipal-level time-invariant heterogeneity, and for any time shocks that affect simultaneously all the municipalities of the same department. $X_{m}$ is a vector of various municipality characteristics measured before the beginning of the peace negotiation that we interact with year fixed effects to flexibly control for differential trends parametrized by each one of the municipal attributes included in the vector. Finally, $\varepsilon_{m d t}$ is the error term, which we cluster at the municipality level. ${ }^{15}$

Our coefficient of interest, $\beta$, captures the average differential change in landmine explosions and victims before and after the beginning of peace negotiation in municipalities with and without prior FARC violent activity. Moreover, our estimation takes into account

\footnotetext{
${ }^{14}$ Municipalities are equivalent to U.S. counties and departments to U.S. states. There are around 1,100 municipalities in Colombia distributed in 32 mainland departments plus the Caribbean island of San Andrés. Our sample excludes the latter as well as the capital city, Bogota, which constitutes its own department. We thus end up with 31 departments, with the average department including 35 municipalities.

${ }^{15}$ For robustness, we follow Conley (1999) and Conley (2016) and estimate equation (5.1) using a variancecovariance matrix that takes into account cross-sectional dependence in the error term.
} 
any municipality characteristics that do not vary over time, as well as any differential trends in landmine victimization that are different across departments.

5.1. Within municipality variation. Alternatively, we can exploit the fact that landmine explosion events are georeferenced and exploit within-municipality variation across grids of $10 \mathrm{Km}^{2} .{ }^{16}$ In this case, FARC-exposure is defined according to whether grid $g$ experienced a FARC-planted landmine explosion prior to the start of the peace negotiations. This specification allows us to include municipality-year fixed effects thus accounting for municipality level non-linear trends in the outcome. In particular, we estimate the following equation:

$$
y_{g m t}=\alpha_{g}+\lambda_{m t}+\beta \times\left(\text { Negotiation } t \times F A R C_{g}\right)+\varepsilon_{g m t}
$$

where the sub-index $g$ refers to $10 \mathrm{Km}^{2}$ grids, $\alpha_{g}$ are grid fixed effects and $\lambda_{m t}$ are municipality-year fixed effects that flexibly control for any municipality-specific shock. $F A R C_{g}$ is a dummy that takes the value one if there was an explosion in that grid between 2007 and 2012 that was associated with FARC.

5.2. Identifying assumption. The main assumption of our empirical strategy is that, had peace negotiations not taken place, landmine explosions and victims would have followed a similar trajectory in municipalities exposed to FARC violence and in areas without FARC violent activity. The validity of this "parallel trends" assumption can be partially assessed by estimating the following non-parametric version of equation (5.1):

$$
y_{m d t}=\alpha_{m}+\lambda_{d t}+\sum_{j \in J} \beta_{j} \times\left(F A R C_{m} \times \delta_{j}\right)+\epsilon_{m d t},
$$

where $J$ includes all years in our sample except from 2012, which is the year before the beginning of the peace negotiations. Therefore, the parameters $\beta_{j}$ can be interpreted as the differential landmine victimization in municipalities exposed to FARC violence

\footnotetext{
${ }^{16}$ The geo-location of landmine victims, however, entails some measurement error, which we try to reduce with the relatively large size of the arbitrary grids. In any case, the within municipality results must be interpreted with caution.
} 
relative to non-exposed places, in year $j$ relative to the year preceding the beginning of the peace negotiations. In addition, we also implement the parametric test suggested by Muralidharan and Prakash (2017). ${ }^{17}$ Moreover, we check for both pre-differential trend bias (Roth, 2021) and for small linear and non-linear potential deviations from the parallel trend assumption (Rambachan and Roth, 2021).

5.3. Heterogeneous effects to test potential mechanism. We study the role of potential mechanism by estimating heterogeneous effects parametrized by municipality characteristics. To do this, we estimate an augmented version of equation (5.1). The specification is saturated with the two-way interaction of the mechanism and the post-negotiation dummy, as follows:

$$
\begin{aligned}
y_{m d t} & =\beta \times\left(\text { Negotiation }_{t} \times F A R C_{m} \times H_{m}\right)+\gamma \times\left(\text { Negotiation }_{t} \times F A R C_{m}\right) \\
& +\delta \times\left(\text { Negotiation }_{t} \times H_{m}\right)+\sum_{c \in \mathbf{X}_{\mathbf{m}}} \gamma^{\prime}\left(c \times \delta_{t}\right)+\alpha_{m}+\lambda_{d t}+\varepsilon_{m d t}
\end{aligned}
$$

where $H_{m}$ is a municipal characteristic measured prior to the start of the peace negotiations.

\section{RESUlts AND ROBUSTNESS}

This section summarizes the results regarding the impact of the peace negotiations on landmine explosions and victims, assess the validity of the parallel-trends assumption, and report a battery of robustness tests.

Table 1 reports the main results for two outcomes: the hyperbolic sine transformation of the total number of landmine explosions (Columns 1 to 3 ), and that of landmine victims (Columns 4 to 6). Columns 1 and 4 include municipality and year fixed effects. Columns 2 and 5 replace the latter with department-year fixed effects, and Columns 3 and 6 add

\footnotetext{
${ }^{17}$ In particular, we estimate: $y_{m d t}=\alpha_{m}+\lambda_{d t}+\beta \times\left(F A R C_{m} \times\right.$ Trend $\left._{t}\right)+\epsilon_{m d t}$, where $\operatorname{Trend}_{t}$ is a linear trend. This model is estimated in the pre-negotiation period.
} 
pre-negotiation municipality characteristics interacted with year fixed effects. ${ }^{18}$ Column 7 reports the within-municipality estimates that exploit variation across $10 \mathrm{Km}^{2}$ grids and include municipality-year fixed effects. Standard errors clustered at the municipality level are reported in parentheses and p-values that account for spatial as well as time correlations (Conley, 1999, 2016) in brackets.

The estimates are robust across specifications. Using our most demanding specification (Column 3), we find evidence consistent with our first hypothesis. This is that after the beginning of the peace negotiations, there was a statistically significant differential reduction of 39 percent in the number of landmine explosions in municipalities affected by FARC violence (Column 3). ${ }^{19}$ Similarly, we find a differential reduction of 45 percent in the number of landmine victims (Column 6). Taking into account that the average yearly number of landmine victims during the period 2007-2012 (prior to the start of the peace negotiations) is 717 , this reduction implies that the peace negotiations and the subsequent agreement saved, on average, 323 lives per year, only from antipersonnel landmine accidents. This is equal to two-thirds of the total number of homicides in New York City in 2021. Using the Value of a Statistical Life (VSL) estimated for Colombia (Mardones and Riquelme, 2018, \$0.64 million USD), we estimate that the lives saved yield annual savings of over $\$ 200$ million USD.

Our detailed information about landmine victims also allows us to estimate the differential effect of the start of the peace negotiations on different victim types. Specifically, we look at victim characteristics (Table 2) as well as at the activity of the victims and the identity of the groups placing the landmine (Table 3). ${ }^{20}$ Using our most demanding specification, Columns 1 and 2 of Table 2 suggest that the documented drop in landmine

\footnotetext{
${ }^{18}$ The set of municipality characteristics includes the total population, a coca suitability index, a rurality index, and a poverty index.

${ }^{19}$ As suggested by Bellemare and Wichman (2020), we compute the percentage change in the outcomes subject to a hyperbolic sine transformation as $e^{\hat{\beta}}-1$.

${ }^{20}$ In both tables, we present $\mathrm{p}$-values that control for the family-wise error rate in multiple hypotheses testing, following Jones et al. (2019) and Westfall and Young (1993).
} 
explosions benefited both public forces personnel and civilians. The magnitude of the effect is substantial in both cases, but larger for the former. Public force (civilian) victims differentially decreased 39 (27) percent after the start of peace negotiations in places previously affected by FARC violence. Columns 3 and 4 show that the drop in victims occurs both for fatal victims (42 percent reduction) and those injured by the explosions (21 percent). Columns 5 and 6 suggest that most of the drop in victimization is driven by adults (44 percent reduction) rather than kids ( 8 percent). In turn, Columns 1 and 2 of Table 3 show that the bulk of the victims saved by the peace negotiation were not conducting manual eradication of illicit crops (around which landmines are generally deployed for protection purposes). Consistent with our treatment definition, Columns 3 and 4 suggest that the reduction is larger for victims of landmines planted by the FARC relative to those that can be adjudicated to other guerrilla organizations.

6.1. Identifying assumption. In Figure 2, we present the estimates from equation (5.3), which yields non-parametric estimates of the year-by-year differential landmine explosions/victims. This dynamic specification has two purposes. First, the differential evolution of the outcome before the beginning of the peace negotiation across FARC exposed and non-exposed municipalities is suggestive of the validity of the parallel-trends assumption. Second, post-negotiation trends are indicative of the dynamics of the treatment effect.

Reassuringly, we find no evidence of differential trends in the pre-peace negotiation years for neither of the main outcomes. In all panels, the p-values for the joint significance test do not reject the null of all coefficients being equal to zero at conventional levels. ${ }^{21}$ Moreover, we find dynamic treatment effects after the beginning of the peace-negotiation that decrease gradually (become larger in absolute value) between 2013 and 2016 and then stabilize -at an almost 100\% decrease in the number of landmine explosions/victims-from 2017 onward. These dynamics support our second hypothesis and are consistent with the

\footnotetext{
${ }^{21}$ The only exception is Panel E which has a p-value of 0.09 .
} 
timing of the peace negotiations (that lasted from 2013 to 2016) and with the signing of the peace agreement at the end of $2016 .^{22}$

Turning to the parametric test described in section 5, we find that the estimate of the differential trend is small and non-statistically significant (see Column 1 of Table 4). Furthermore, we estimate a placebo test where we run the main regression (5.1) but we limit the sample period to the pre-peace negotiation years and arbitrarily assign the time variation to the year after the election of President Santos in 2010. Again, the coefficient associated with the interaction of interest is small and non-statistically significant (Column 2).

We also check for pre-testing bias and bias from a pre-peace negotiation linear trend following Roth (2021), and estimate confidence sets for our parameter of interest that allow for moderate deviations of the parallel trend assumption following Rambachan and Roth (2021). These results are reported in Appendix A2.1.

\subsection{Robustness.}

6.2.1. Inference. To further assess the robustness of our standard errors, we follow Bertrand et al. (2004) and collapse our data before and after the start of peace dialogues as a way to deal with potential serial correlation in the dependent variable. Column 3 of Table 4 reports these results, which reassure the validity of the baseline estimates of Table 1 . We also conduct a permutation test by randomly assigning -over many iterations-an indicator of exposure to FARC violence across municipalities. We do so in a way that is consistent with the observed distribution of municipalities exposed to FARC violence prior to the start of the peace negotiation. This provides us with a distribution-free estimate of the probability that our coefficient of interest arises by chance. The results are reported in

\footnotetext{
${ }^{22}$ Appendix Figure A3 presents the equivalent dynamic specification for equation (5.2), which exploits grid-level variation, and finds similar conclusions. Likewise, Appendix Figure A4 reports the dynamic estimates for the types of victims, and also finds similar results for all of them. This is true for both the lack of pre-negotiation differential trends and the posterior dynamics.
} 
Figure A8 of the Appendix. Reassuringly, our estimated coefficients (red vertical line) are well above the 99th percentile of the resulting distributions.

6.2.2. Comparison group. One threat to identification is that municipalities exposed to FARC violence are different from areas not exposed along non-observed characteristics, some of which may have been exposed to shocks other than the start of peace negotiations after 2013. In turn, the shock-driven differential change in these characteristics may affect FARC-exposed municipalities for reasons other than our treatment of interest. A second potential thread is that municipalities that were not exposed to FARC violence prior to the start of the peace negotiations were not at all affected by the presence and the explosion of landmines, neither before nor after the peace talks. If this was the case, our difference-in-differences analysis would in fact reduce to a simple 'before and after' comparison within the treatment group. This is however not the case since, as described in section 2, Colombia's conflict has traditionally featured several illegal armed groups other than FARC, and thus the agreement with this insurgency (arguably the largest and most important of all such groups) de facto yielded a partial peace, with other armed groups exerting violence (and in some cases using landmines) during our entire sample period.

However, to further alleviate these concerns, we estimate our main model using different sets of control municipalities. First, we follow Crump et al. (2009) and truncate the sample based on the distribution of a propensity score in order to increase the overlap between FARC and non-FARC-affected municipalities. ${ }^{23}$ Column 4 of Table 4 shows that the results are robust to changing the control group in this way, and also of similar magnitude relative to the baseline estimates. The results are similar if instead of truncating, we use a decaying weight that accounts for the fact that the propensity score is estimated (as suggested by Yang and Ding, 2018, see Column 5).

\footnotetext{
${ }^{23}$ We use the following municipal characteristics to construct the propensity score: a poverty and rurality indexes, municipality area, distance to the county's capital, to Venezuela, and the ocean, total population, coca, cocoa, gold, and palm suitability, and coffee plantations. The resulting optimal cut-off is $5.2 \%$.
} 
Second, we implement a recently developed synthetic difference-in-differences estimator that allows us to choose the comparison group that best matches the trends (and levels) of our outcome variables in FARC-affected municipalities prior to the start of peace negotiations (Arkhangelsky et al., 2021). We find similar results in terms of magnitude and significance. The estimated result is reported in Column 6 and its corresponding dynamic version can be seen in Appendix Figure A9. The latter shows the fit of the synthetic control as well as the divergence of the actually treated municipalities since 2013.

Third, we restrict the control group to municipalities affected by conflict just prior to the start of the peace negotiations. We again find similar results, and if anything we find larger effects (Column 7). Forth, following Belloni et al. (2014), we select the set of prenegotiation municipality characteristics using machine learning. ${ }^{24}$ Column 8 shows that the results are robust to this exercise. Fifth, as suggested by Abadie (2005), we re-estimate the baseline model weighting the observations by a propensity score of the probability of being exposed to FARC violence. ${ }^{25}$ Column 9 reports the estimates obtained from the inverse probability weighting. The results are of similar size and significance.

As a last robustness test, we follow Sant'Anna and Zhao (2020) and estimate a doublyrobust version of our baseline specification in which the effect of the start of peace negotiations on landmine explosions and victimization is robust to either misspecification of the propensity score or misspecification of the linear model that flexibly adds pre-treatment controls. Again, the results are stable when estimating such a specification (Column 10).

Finally, in Appendix A2.1.1, we show the robustness of our main results to different transformations of the dependent variable or different measures of our treatment variable, i.e., exposure to FARC violence. Furthermore, in Appendix A2.1.2 we present the robustness to influential observations.

\footnotetext{
${ }^{24}$ The pool of potential municipality characteristics is the same reported in footnote 23 .

${ }^{25}$ To compute the propensity score, we use the machine learning selected controls discussed in the previous test.
} 


\section{MEChANismS}

What explains the large documented reduction in landmine explosions and victimization after the start of peace talks in Colombia? Understanding the potential mechanisms that drive our findings is important to design policies that help reduce the burden posed by active underground explosives throughout the world, especially in countries that are either conflict-affected or transitioning through the first stages of post-conflict.

Clearly, an obvious reason that may drive down landmine explosions and victimization is that, first to show its commitment to the peace dialogues and then to comply with the terms of the agreement, FARC stopped planting landmines. While this is not unlikely, we argue that the buried landmines backlog in Colombia is so large that even if the flow of planted landmines completely stopped in 2013 this could not account for the magnitude of our estimated effects. Indeed, in this section, we empirically document the potential relevance of a number of additional mechanisms related to municipal characteristics and policy instruments.

7.1. Military initiative. First, we re-estimate equation (5.1) using as dependent variables the number of attacks perpetrated by the Colombian army, as a proxy of the military initiative of the legitimate armed forces. We find a large differential reduction of this variable in FARC-affected municipalities after the start of peace negotiations (Column 1 of Table 5). This could at least partially account for the documented reduction in the number of landmine victims from the armed forces (Column 1 of Appendix Table A5).

In addition, we test the role of other potential mechanisms by estimating an augmented version of equation (5.1) in which we multiply the interaction of interest (that of the post-negotiation-start time indicator and the FARC exposure dummy) with a municipal characteristic that accounts for variation in a potential mechanism. ${ }^{26}$ The results are reported in Table 5.

\footnotetext{
$\overline{{ }^{26} \text { See equation }}(5.4)$ in Section 5.
} 
7.2. Ex-combatants collaboration. One direct mechanism by which the start of peace negotiations -and the eventual signing of a peace agreement-helps reduce landmine explosions is the information that demobilizing combatants may provide to the government. In his memoirs about the peace process - that took place amid his term in office- president Juan Manual Santos acknowledged the key role of ex-combatants in identifying minefields (Santos, 2019). The United Nations, which oversees the implementation of the peace agreement, has also documented the contribution of former FARC members. ${ }^{27}$ Clearly, the incentive to provide information about the location of minefields depends on the extent to which former combatants can benefit from it. There are at least two reasons that were the case in the Colombian setting. On the one hand, the majority of demobilized troops relocated in specific areas targeted by the government to speed up the reincorporation process of former combatants. ${ }^{28}$ Clearly, reintegrated ex-combatants can benefit as much as host communities from mine removal activities in such areas. On the other hand, the main source of income of many former guerrillas comes from their job in civilian organizations that have been approved by the government to engage in humanitarian demining activities. In fact, one such organization, namely Humanicemos DH came directly from the peace agreement and is entirely composed by reincorporating former combatants.

As a way to test this potential mechanism more formally, we explore heterogeneous effects according to an indicator that identifies ETCR municipalities. Columns 2 and 3 of Table 5 show that the documented differential effect of the start of the peace dialogues in FARC-exposed areas is exacerbated in places where former FARC soldiers settled. ${ }^{29}$ Consistent with our third hypothesis, while the post-negotiations-start reduction in landmine explosions (victims) in municipalities with no ex-FARC soldiers is 29 (34) percent, that in areas with the presence of former fighters is 44 (52) percent. Because landmines

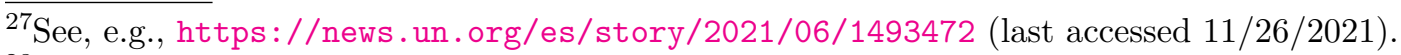

${ }^{28}$ These areas are called Territorial Spaces for Training and Reincorporation (ETCR from the Spanish acronym).

${ }^{29}$ As the re-settlement of ex-combatants occurred after reaching a final peace agreement in 2016. These heterogeneous effects should be interpreted with caution.
} 
are unobserved and cannot be detected without the appropriate technology, reducing the information asymmetry is of foremost importance for their removal. This is obviously facilitated by a post-conflict setting.

The magnitude of the reduction of landmine victims in ETCR municipalities allows us to back out a figure for the economic value of the information provided by demobilized guerrillas. Because during 2007-2012 an average of 445 people died from landmine accidents in these municipalities, the 52 percent reduction in landmine victimization estimated for these areas implies an average of 231 lives saved there every year between 2013 and 2019 . In turn, using the VSL available for Colombia, this yields savings that amount to $\$ 148$ million USD per year.

7.3. Humanitarian demining. Another direct potential mechanism is the implementation of demining operations. In Colombia, the start of humanitarian demining campaigns, which have the objective of clearing entire mined fields with the collaboration of local communities, picked up since 2013 after the issuing of Decree 3570 of 2011 that established that any national or foreign NGO could undertake demining campaigns.

To formally test this idea, we explore the heterogeneous effects of our main results in places that experienced any humanitarian demining operation from 2013 to $2019 .{ }^{30}$ The results are reported in Columns 4 and 5. Consistent with our fourth hypothesis, while the post-negotiations-start reduction in landmine explosions (victims) in municipalities with no humanitarian demining is 30 (37) percent, that of municipalities with landmine-cleared areas is 49 (56) percent. Naturally, the extent to which mined fields are effectively cleared from the landmine threat is both a life-saving activity and one that is unlikely to carry out amidst an ongoing conflict.

Similar to the case of the information provided by former FARC combatants, the magnitude of the reduction of landmine victims in municipalities that experienced humanitarian

\footnotetext{
${ }^{30}$ Because humanitarian demining took place after the start of the peace negotiations the same warning of footnote 29 is in order.
} 
demining allows us to compute the average yearly return of the investment made by both the Colombian government and the international community in humanitarian demining efforts. First, we compute the economic value of the lives saved by humanitarian demining: Because during 2007-2012 an average of 287 people died because of landmine accidents in municipalities eventually targeted by this policy, the 56 percent reduction in the number of landmine victims estimated for these areas implies that, on average, 161 lives were saved there every year between 2013 and 2019. Using the VSL figure, this yields savings that amount to $\$ 103$ million USD per year. Second, we compare this figure with the cost of humanitarian demining, which is about $\$ 40$ million per year (OACP, 2020). We, therefore, conclude that the economic value of the lives saved by humanitarian demining is 2.6 times greater than its average yearly cost. ${ }^{31}$

7.4. Mine Risk Education programs. In addition to demining operations, the start of the peace process triggered the design and implementation of Mine Risk Education (henceforth, MRE) programs, that seek to promote -among civilians in landmine-affected areas-a culture of safe behaviors and best practices to avoid landmine accidents. MRE protocols were designed by the Integral Action Against Mines group of Colombia's Office of the High Commissioner of Peace, but can be implemented by any accredited civic society organization. ${ }^{32}$ MRE has three main components: i) timely diffusion of information about the suspected presence of landmine or UXO in specific areas; ii) educational activities to promote behavioral changes through group experiences and the teaching of good practices; and iii) the strengthening of local community organizations to promote the establishment of local standards to prevent landmine accidents.

\footnotetext{
${ }^{31}$ Humanitarian demining also has large economic benefits, as estimated by Prem et al. (2022a). The authors argue that it increases the annual GDP growth rate by around 0.7 percent and, consequently, each dollar invested in this policy yields about $\$ 7$ in return when focusing on this metric only.

${ }^{32}$ The document that establishes the principles and approaches of MRE, and that details the standardized processes for effective MRE initiatives can be found here: http://www.accioncontraminas.gov.co/ AICMA/Documents/Estandares_Nacionales/190109-EN-ERM.pdf (last accessed 28/11/2022).
} 
Since the start of the peace process in 2013, hundreds of thousands of civilians in landmines affected areas have been exposed to MRE programs. Importantly, because MRE programs can be implemented in areas not yet demined, this constitutes a different source of heterogeneity than the areas subject to humanitarian demining. We formally test the idea that landmine accidents were further reduced by the implementation of MRE endeavors by exploring the heterogeneous effects of our main results in places that experienced any MRE from 2013 to 2019. The results are reported in Columns 5 and 6 of Table 5. Consistent with our fourth hypothesis, while the post-negotiations-start reduction in landmine explosions (victims) in municipalities with no MRE activity is 15 (19) percent, that of municipalities exposed to this policy is 35 (42) percent.

The estimated reduction of landmine victims in municipalities that experienced MRE allows us to compute the average yearly return of this endeavor. On the one hand, using the fact that during 2007-2012 an average of 463 people died from landmine accidents in municipalities eventually subject to MRE, the 42 percent reduction in the number of victims estimated for these areas implies that, on average, 193 lives were saved there every year between 2013 and 2019. This translates into yearly savings of $\$ 124$ million USD. On the other hand, we use figures reported by Mutual-Co (2021) for a subset of the country to estimate the average annual cost of MRE programs at 6.9 million USD since 2013. Thus, we conclude that the yearly economic benefits of MRE are 18 times greater than their costs.

7.5. Coca fields. Finally, and related to the information mechanism -although in a more indirect way-the existence of illegal coca fields can potentially reveal the location of landmines. Upon the start of the peace negotiations, when FARC's offensive activity substantially dropped as a way to show the insurgency's commitment to reach a peace agreement, this constituted a window of opportunity for the authorities to engage in landmine removal. 
We test this idea by exploring potential heterogeneous effects in areas with high and low suitability to grow coca. Columns 8 and 9 suggest that the differential reduction in landmine explosions and victims that followed the start of peace talks was exacerbated in areas highly suitable to grow coca. While in low-suitability areas explosions (victims) dropped by 32 (39) percent, in highly coca suitable areas the reduction was 48 (53) percent. This is consistent with the idea that non-direct information channels can also help reduce the threat of antipersonnel landmines.

Because during 2007-2012 an average of 302 people died from landmine accidents in municipalities with high coca suitability, the 53 percent reduction in the number of victims estimated for these areas implies that, on average, 161 lives were saved there every year between 2013 and 2019. This translates into yearly savings of $\$ 103$ million USD.

7.6. Overall peacetime victimization. Finally, instead of the result of a specific set of peacetime policies and investments aimed at reducing the threat of antipersonnel landmines, the documented reduction of landmine victimization could just be a manifestation of an overall security improvement following the peace talks. Indeed, FARC's offensive dropped almost completely during that period (CERAC, 2016).

To explore this alternative explanation, we re-estimate equation (5.1) using as a dependent variable the number of homicides, the paramount variable to measure overall violence. The results are reported in Columns 1 and 2 of Appendix Table A7. Using our preferred specification, which includes municipality fixed effects as well as department $\times$ time fixed effects and pre-determined municipal controls, our estimated coefficient implies a differential reduction in homicides in FARC-affected areas following the start of peace negotiations of 16 percent. ${ }^{33}$ However, note that, while meaningful in terms of magnitude, the percent reduction in the number of homicides is just a third of that of landmine victims. Importantly, moreover, Columns 3 to 6 of Appendix Table A7 show that neither of the

\footnotetext{
${ }^{33}$ Moreover, Appendix Figure A10 corroborates that this effect is likely causal because of the absence of pre-negotiation differential pre-trends.
} 
heterogeneous effects explored in this section, that account for the potential mechanisms of the drop in landmine explosions, is present in the case of homicides. ${ }^{34}$

\section{Conclusions}

This paper documents how peace negotiations have the potential to significantly reduce conflict victimization, and specifically that coming from the explosions of landmines. This is relevant, as landmines are a silent but dangerous and potentially long-lasting social and economic threat in conflict-affected countries. Focusing on the recent experience of Colombia, we study both the types of victims saved by the peace negotiations between the central government and the FARC insurgency, as well as the conditions that make landmine explosions and victimization being more pronounced.

Our findings suggest that peace negotiations in which parties are committed to reaching an agreement and collaborating for the common goal of reducing the hazard of hidden explosives can be a successful way to reduce the victimization of both combatants and civilians. For the specific case of Colombia, our most conservative estimates suggest that landmine victimization differentially dropped by almost 50 percent after the start of the peace negotiations, saving hundreds of lives and over $\$ 200$ million every year.

In particular, we emphasize the mutually reinforcing role played by the reduction of the military initiative, the sharing of intelligence and information among former enemies, and providing access and support to NGOs that are capable to engage in humanitarian mine clearance. Taken together, these findings emphasize the importance of negotiated solutions to ongoing conflicts, particularly in places affected by unexploded UXO and antipersonnel landmines.

\footnotetext{
${ }^{34}$ Adding to the fact that the large reduction in landmine victimization following the start of the peace agreement is unlikely driven by an overall improvement in security, Prem et al. (2022b) show that during the same period other security indicators deteriorated. Indeed, the authors document that the ceasefire declared by FARC at the end of 2014 amid the peace talks triggered an escalation of selective killings of local leaders in former FARC strongholds.
} 


\section{REFERENCES}

AbAdie, A. (2005): "Semiparametric difference-in-differences estimators," The Review of Economic Studies, 72, 1-19.

Acevedo, K., I. D. Bornacelly Olivella, et Al. (2014): "Panel municipal del CEDE," .

Arkhangelsky, D., S. Athey, D. A. Hirshberg, G. W. Imbens, and S. Wager (2021): "Synthetic difference-in-differences," American Economic Review, 111, 40884118.

Bellemare, M. F. And C. J. Wichman (2020): "Elasticities and the inverse hyperbolic sine transformation," Oxford Bulletin of Economics and Statistics, 82, 50-61.

Belloni, A., V. Chernozhukov, and C. Hansen (2014): "High-dimensional methods and inference on structural and treatment effects," Journal of Economic Perspectives, 28, 29-50.

Bernal, C., M. Ortiz, M. Prem, M. E. Purroy, and J. F. Vargas (2022): "Peaceful Entry: Entrepreneurship dynamics during Colombia's peace agreement," .

Bertrand, M., E. Duflo, And S. Mullainathan (2004): "How much should we trust differences-in-differences estimates?" The Quarterly Journal of Economics, 119, 249-275.

Blattman, C. And E. Miguel (2010): "Civil war," Journal of Economic Literature, $48,3-57$.

CERAC (2016): "Un año de desescalamiento: conflicto casi detenido, pero que se resiste a desaparecer," Monitor de Desescalamiento del Conflicto Armado Interno en Colombia, 12.

Chiovelli, G., S. Michalopoulos, and E. Papaionnnou (2019): "Landmines and spatial development," .

Conley, T. G. (1999): "GMM estimation with cross sectional dependence," Journal of Econometrics, 92, 1-45. 
(2016): Spatial Econometrics, London: Palgrave Macmillan UK, 1-9.

Crump, R. K., V. J. Hotz, G. W. Imbens, and O. A. Mitnik (2009): "Dealing with limited overlap in estimation of average treatment effects," Biometrika, 96, 187-199.

de Groot, O. J., C. Bozzoli, A. Alamir, And T. BrücK (2022): "The global economic burden of violent conflict," Journal of Peace Research, 59, 259-276.

De Roux, N. And L. R. Martinez (2021): "Forgone Investment: Civil Conflict and Agricultural Credit in Colombia," .

Dell, M. AND P. Querubin (2018): "Nation building through foreign intervention: Evidence from discontinuities in military strategies," The Quarterly Journal of Economics, 133, 701-764.

Eck, K. And L. Hultman (2007): "One-sided violence against civilians in war: Insights from new fatality data," Journal of Peace Research, 44, 233-246.

Fergusson, L. (2019): "Who wants violence? The political economy of conflict and state building in Colombia," Cuadernos de Economía, 38, 671-700.

Gibilisco, M., B. Kenkel, And M. R. Rueda (2022): "Competition and Civilian Victimization," Journal of Conflict Resolution, 66, 809-835.

Guerra-Cújar, M. E., M. Prem, P. A. Rodríguez-Lesmes, and J. F. Vargas (2021): “A Peace Baby Boom? Evidence from Colombia's Peace Agreement," .

Jones, D., D. Molitor, And J. ReIF (2019): "What do workplace wellness programs do? Evidence from the Illinois workplace wellness study," The Quarterly Journal of Economics, 134, 1747-1791.

Kalyvas, S. N. (2006): The Logic of Violence in Civil War, Cambridge Studies in Comparative Politics, Cambridge University Press.

Kreutz, J. (2010): "How and when armed conflicts end: Introducing the UCDP Conflict Termination dataset," Journal of Peace Research, 47, 243-250.

LANDMINe Monitor (2017): "Landmine Monitor 2017," Discussion paper ICBL and $C M C$.

(2019): "Landmine Monitor 2019," Discussion paper ICBL and CMC. 
LIN, E. (2020): "How war changes land: Soil fertility, unexploded bombs, and the underdevelopment of Cambodia," American Journal of Political Science.

Mardones, C. And M. Riquelme (2018): "Estimation of the value of statistical life in Chile and extrapolation to other Latin American countries," Latin American Research Review, 53.

Mason, S. J. And M. Siegfried (2013): "Confidence building measures (CBMs) in peace processes," Managing Peace Processes: Process related questions. A handbook for AU practitioners, 1, 57-77.

Mejía, D. And P. Restrepo (2015): "Bushes and bullets: Illegal cocaine markets and violence in Colombia." Documentos CEDE.

Miguel, E. AND G. Roland (2011): "The long-run impact of bombing Vietnam," Journal of Development Economics, 96, 1-15.

Muralidharan, K. And N. Prakash (2017): "Cycling to school: Increasing secondary school enrollment for girls in India," American Economic Journal: Applied Economics, $9,321-50$.

Mutual-Co (2021): "External Evaluation: Comprehensive Mine Action In Algeciras. Project No. 7F-09980.02.01," .

OACP (2020): "Plan Estratégico 2020-2025 "Hacia una Colombia libre de sospecha de minas anteperconal para todos los colombianos"," .

Prem, M., M. E. Purroy, and J. F. Vargas (2022a): "Landmines: The local effects of demining," .

Prem, M., A. Rivera, D. Romero, and J. F. Vargas (2022b): "Selective civilian targeting: The unintended consequences of partial peace," Quarterly Journal of Political Science, 17, 317-354.

Prem, M., S. SaAvedra, And J. F. Vargas (2020): "End-of-conflict deforestation: Evidence from Colombia's peace agreement," World Development, 129, 104852.

Prem, M., J. F. VArgas, And D. Mejía (2021a): “The rise and persistence of illegal crops: Evidence from a naive policy announcement," The Review of Economics and 
Statistics, 1-42.

Prem, M., J. F. VArgas, And O. Namen (2021b): "The human capital peace dividend," Journal of Human Resources, 0320-10805R2.

Pulido, A. ET AL. (2019): "Violence, voting \& peace: Explaining public support for the peace referendum in Colombia," Electoral studies, 61, 102067.

Rambachan, A. And J. Roth (2021): "An honest approach to parallel trends," .

Ray, D. And J. Esteban (2017): "Conflict and development," Annual Review of Economics, 9, 263-293.

Restrepo, J., M. Spagat, And J. Vargas (2004): "The dynamics of the Colombian civil conflict: A new dataset." Homo Oeconomicus, 21, 396-429.

Riaño, J. F. And F. Valencia Caicedo (2020): "Collateral damage: The legacy of the secret war in Laos," .

Roth, J. (2021): "Pre-test with caution: Event-study estimates after testing for parallel trends,"

SAntos, J. M. (2019): La batalla por la paz: El largo camino para acabar el conflicto con la guerrilla más antigua del mundo, Editorial Planeta Colombiana.

SAnt'Anna, P. H. AND J. Zhao (2020): "Doubly robust difference-in-differences estimators," Journal of Econometrics, 219, 101-122.

Tellez, J. F. (2019a): "Peace agreement design and public support for peace: Evidence from Colombia," Journal of Peace Research, 56, 827-844.

(2019b): "Worlds apart: Conflict exposure and preferences for peace," Journal of Conflict Resolution, 63, 1053-1076.

Vargas, J. (2016): Strategic Atrocities Civilians under Crossfire: Theory and Evidence from Colombia, Oxford University Press, 425-451.

Vargas, J. F., M. E. Purroy, S. Perilla, F. Coy, And M. Prem (2022): "Fear to Vote: Explosions and Elections in Colombia," .

Westfall, P. H. And S. S. Young (1993): Resampling-based multiple testing: Examples and methods for p-value adjustment, vol. 279, John Wiley \& Sons. 
YANG, S. AND P. Ding (2018): "Asymptotic inference of causal effects with observational studies trimmed by the estimated propensity scores," Biometrika, 105, 487-493. 
Figure 1. Landmine victims and FARC presence

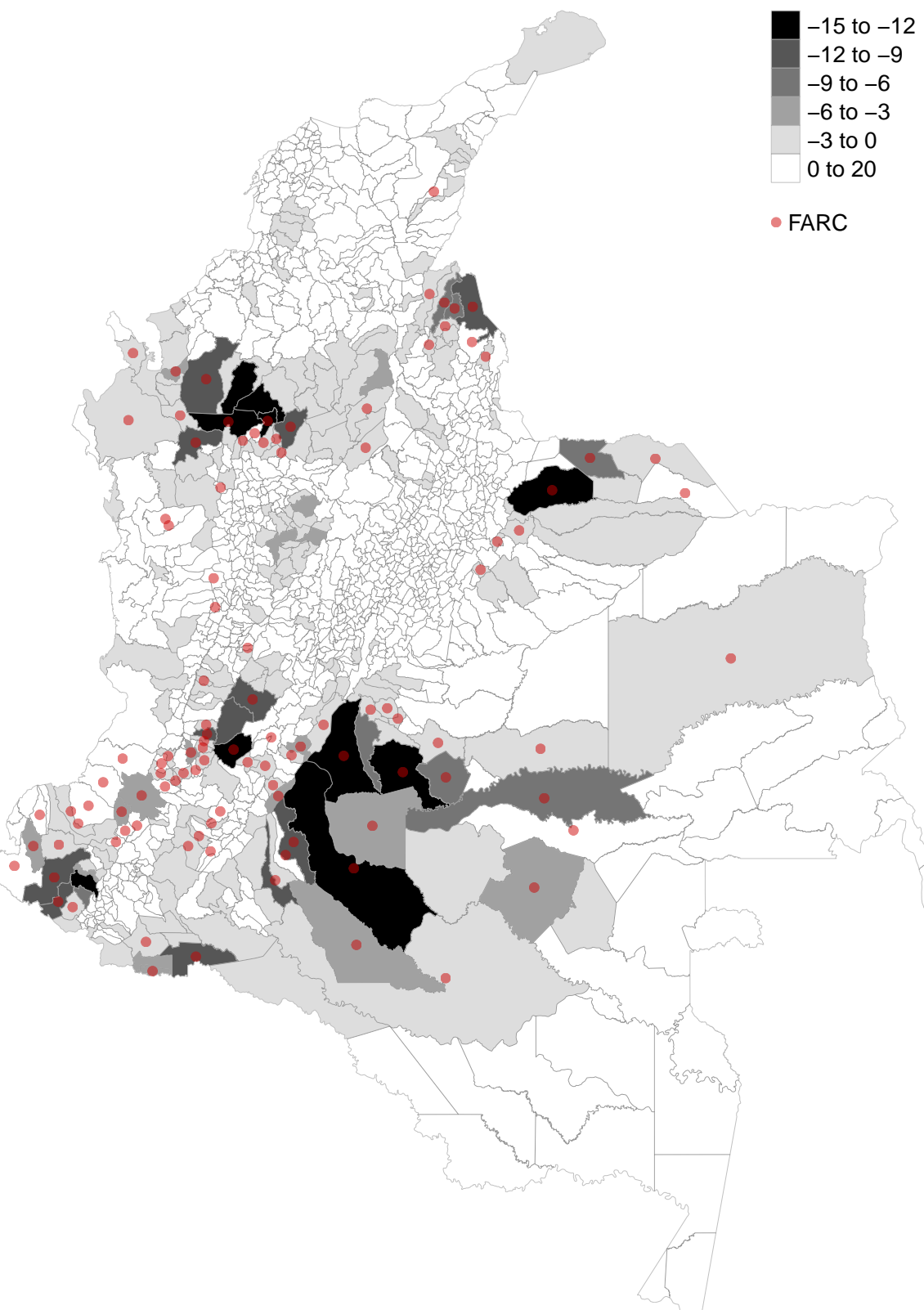

Notes: This map presents the spatial distribution of the difference between landmine victims before and after the beginning of the peace negotiation, and FARC presence - measured as at least one attack in the municipality - between 2011 and 2012 with red dots. 
FiguRE 2. Landmine explosions and victims

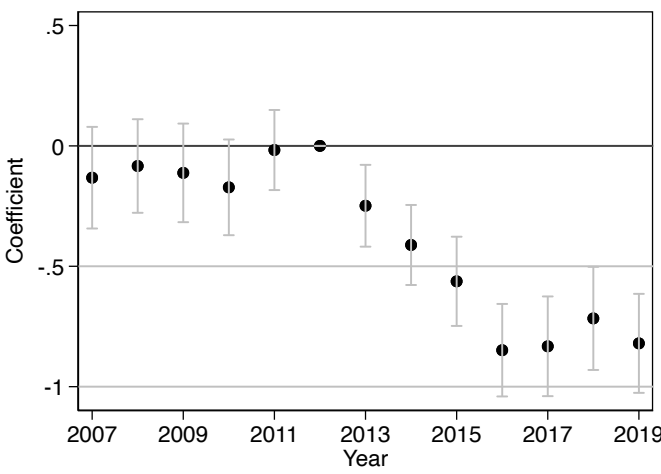

A. Explosions

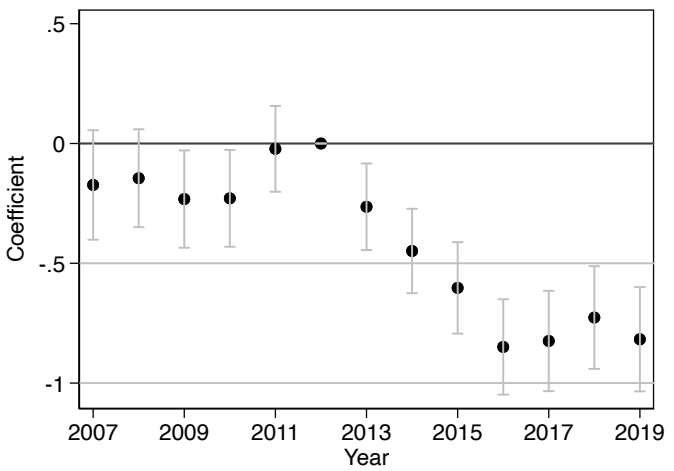

C. Explosions: Adds dep-year FE

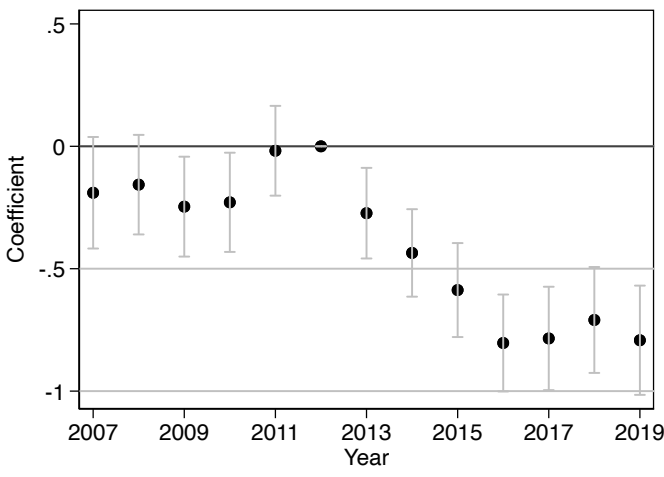

E. Explosions: Baseline controls

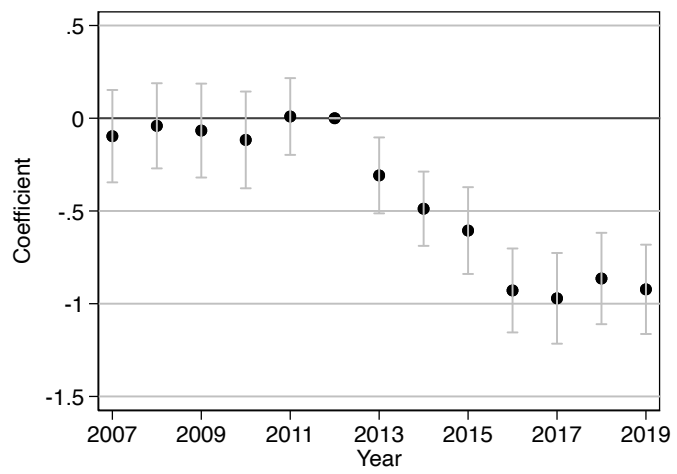

B. Victims

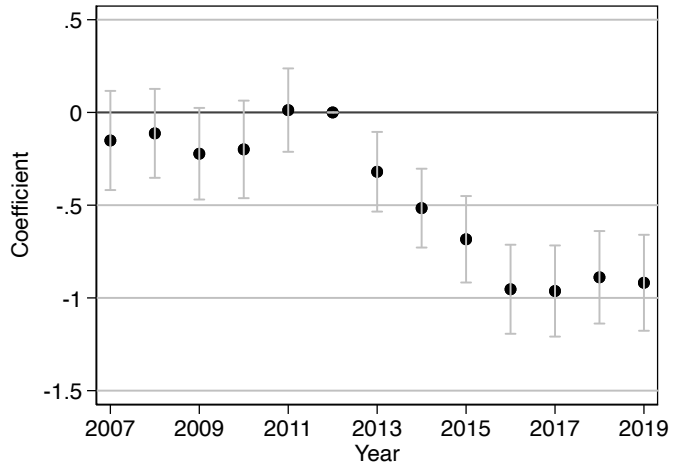

D. Victims: Adds dep-year FE

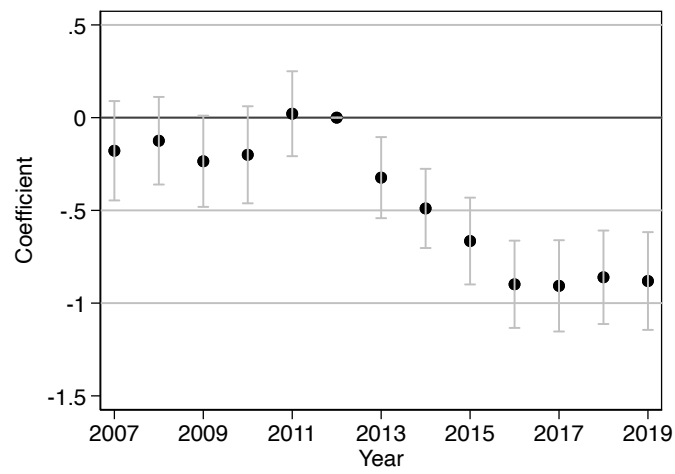

F. Victims: Baseline controls

Notes: This figure presents the estimates from the dynamic difference-in-differences model specified in equation (5.3). The dependent variables in panels A, C, and D (B, D, and F) are the hyperbolic sine transformations of the total number of explosions (victims) in municipality $m$ in year $t$. The set of baseline controls include the total population, a coca suitability index, a rurality index, and a poverty index. All of them interacted with year fixed effects. We present the point estimates as well as the $95 \%$ confidence interval. The p-values for joint significant test of pre-negotiation years being all equal to zero are: 0.48 (Panel A) 0.85 (Panel B) 0.13 (Panel C) 0.31 (Panel D) 0.09 (Panel E) 0.23 (Panel F). 
TABLE 1. Explosions, victims, FARC, and peace negotiations

\begin{tabular}{|c|c|c|c|c|c|c|c|}
\hline \multirow[b]{3}{*}{ FARC $\times$ Negotiation } & (1) & $(2)$ & $(3)$ & $(4)$ & $(5)$ & $(6)$ & (7) \\
\hline & \multicolumn{3}{|c|}{ Explosions } & \multicolumn{4}{|c|}{ Victims } \\
\hline & $\begin{array}{c}-0.55^{* * *} \\
(0.07) \\
{[0.000]}\end{array}$ & $\begin{array}{c}-0.51^{* * *} \\
(0.07) \\
{[0.000]}\end{array}$ & $\begin{array}{c}-0.49^{* * *} \\
(0.07) \\
{[0.000]}\end{array}$ & $\begin{array}{c}-0.67^{* * *} \\
(0.08) \\
{[0.000]}\end{array}$ & $\begin{array}{c}-0.64^{* * *} \\
(0.08) \\
{[0.000]}\end{array}$ & $\begin{array}{c}-0.60^{* * *} \\
(0.08) \\
{[0.000]}\end{array}$ & $\begin{array}{c}-0.37^{* * *} \\
(0.02) \\
{[0.000]}\end{array}$ \\
\hline Observations & 14,196 & 14,196 & 14,196 & 14,196 & 14,196 & 14,196 & 122,837 \\
\hline Municipalities (Grids) & 1092 & 1092 & 1092 & 1092 & 1092 & 1092 & 9449 \\
\hline R-squared & 0.563 & 0.597 & 0.601 & 0.544 & 0.580 & 0.585 & 0.438 \\
\hline Municipality fixed effect & Yes & Yes & Yes & Yes & Yes & Yes & No \\
\hline Year fixed effects & Yes & No & No & Yes & No & No & No \\
\hline Dept-year fixed effect & Yes & Yes & Yes & Yes & Yes & Yes & No \\
\hline Baseline controls & No & No & Yes & No & No & Yes & No \\
\hline Grid fixed effect & No & No & No & No & No & No & Yes \\
\hline Municipality-year fixed effect & No & No & No & No & No & No & Yes \\
\hline Average dep var & 0.175 & 0.175 & 0.175 & 0.207 & 0.207 & 0.207 & 0.038 \\
\hline
\end{tabular}

Notes: This table presents the estimates from the difference-in-differences model specified in equation (5.1). The dependent variables in columns 1 to 3 (4 to 7$)$ are the hyperbolic sine transformations of the total number of explosions (victims) in municipality $m$ in year $t . F A R C$ is a dummy that takes the value one if municipality $m$ experiences a violent event by FARC between 2011 and 2012. Negotiation is a dummy that takes the value from 2013 on wards. The set of baseline controls include the total population, a coca suitability index, a rurality index, and a poverty index. All of them interacted with year fixed effects. In column 7 , we divide the country into grids of $1 \times 1 \mathrm{~km}$ and count the number of victims in each year. The FARC treatment dummy is defined based on the presence of an explosion in that grid between 2007 and 2012 that was associated with FARC. Robust standard errors are clustered at the municipality level presented in parenthesis. In square brackets, we present the p-values for standard errors control for spatial and first-order time correlation (see Conley, 1999, Conley, 2016). We allow spatial correlation to extend to up to $416 \mathrm{~km}$ from each municipality's centroid, which is the average distance from one municipality to all the rest. ${ }^{*}$ is significant at the $10 \%$ level, $* *$ is significant at the $5 \%$ level, $* * *$ is significant at the $1 \%$ level. 
TABLE 2. Victims' characteristics

\begin{tabular}{|c|c|c|c|c|c|c|}
\hline & $\begin{array}{c}(1) \\
\text { Public } \\
\text { force }\end{array}$ & $\begin{array}{c}\text { (2) } \\
\text { Civilian }\end{array}$ & $\begin{array}{c}(3) \\
\text { Injured }\end{array}$ & $\begin{array}{c}(4) \\
\text { Dead }\end{array}$ & $\begin{array}{c}(5) \\
\text { Under } 18 \\
\text { years old }\end{array}$ & $\begin{array}{c}(6) \\
\text { Over } 18 \\
\text { years old }\end{array}$ \\
\hline FARC $\times$ Negotiation & $\begin{array}{c}-0.50^{* * *} \\
(0.08)\end{array}$ & $\begin{array}{c}-0.32^{* * *} \\
(0.05)\end{array}$ & $\begin{array}{c}-0.55^{* * *} \\
(0.08)\end{array}$ & $\begin{array}{c}-0.24^{* * *} \\
(0.04)\end{array}$ & $\begin{array}{c}-0.10^{* * *} \\
(0.02)\end{array}$ & $\begin{array}{c}-0.58^{* * *} \\
(0.08)\end{array}$ \\
\hline Observations & 14,196 & 14,196 & 14,196 & 14,196 & 14,196 & 14,196 \\
\hline Municipalities & 1092 & 1092 & 1092 & 1092 & 1092 & 1092 \\
\hline R-squared & 0.535 & 0.463 & 0.577 & 0.390 & 0.261 & 0.581 \\
\hline Municipality fixed effect & Yes & Yes & Yes & Yes & Yes & Yes \\
\hline Dept-year fixed effect & Yes & Yes & Yes & Yes & Yes & Yes \\
\hline Baseline controls & Yes & Yes & Yes & Yes & Yes & Yes \\
\hline Average dep var & 0.148 & 0.103 & 0.185 & 0.065 & 0.030 & 0.197 \\
\hline MHT p-value & 0.000 & 0.000 & 0.000 & 0.000 & 0.000 & 0.000 \\
\hline
\end{tabular}

Notes: This table presents the estimates from the difference-in-differences model specified in equation (5.1). The dependent variables are the hyperbolic sine transformation for the different measure of the types of victims. $F A R C$ is a dummy that takes the value one if municipality $m$ experiences a violent event by FARC between 2011 and 2012. Negotiation is a dummy that takes the value from 2013 on wards. The set of baseline controls include the total population, a coca suitability index, a rurality index, and a poverty index. All of them interacted with year fixed effects. Robust standard errors are clustered at the municipality level presented in parenthesis. We also present p-values that control for the family-wise error rate in multiple hypotheses testing following Jones et al. (2019) and Westfall and Young (1993). * is significant at the $10 \%$ level, ** is significant at the $5 \%$ level, *** is significant at the $1 \%$ level. 
TABLE 3. Victims' activity and perpetrator

\begin{tabular}{|c|c|c|c|c|}
\hline & $\begin{array}{c}(1) \\
\text { Non } \\
\text { eradication }\end{array}$ & $\begin{array}{c}(2) \\
\text { In } \\
\text { eradication }\end{array}$ & $\begin{array}{c}(3) \\
\text { Related } \\
\text { to FARC }\end{array}$ & $\begin{array}{c}(4) \\
\text { Non-related } \\
\text { to FARC }\end{array}$ \\
\hline FARC $\times$ Negotiation & $\begin{array}{c}-0.58^{* * *} \\
(0.08)\end{array}$ & $\begin{array}{c}-0.08^{* * *} \\
(0.03)\end{array}$ & $\begin{array}{c}-0.36^{* * *} \\
(0.06)\end{array}$ & $\begin{array}{c}-0.30^{* * *} \\
(0.05)\end{array}$ \\
\hline Observations & 14,196 & 14,196 & 14,196 & 14,196 \\
\hline Municipalities & 1092 & 1092 & 1092 & 1092 \\
\hline R-squared & 0.580 & 0.301 & 0.527 & 0.530 \\
\hline Municipality fixed effect & Yes & Yes & Yes & Yes \\
\hline Dept-year fixed effect & Yes & Yes & Yes & Yes \\
\hline Baseline controls & Yes & Yes & Yes & Yes \\
\hline Average dep var & 0.201 & 0.0172 & 0.102 & 0.108 \\
\hline MHT p-value & 0.000 & 0.000 & 0.009 & 0.000 \\
\hline
\end{tabular}

Notes: This table presents the estimates from the difference-in-differences model specified in equation (5.1). The dependent variables are the hyperbolic sine transformation for the different measure of the types of victims. $F A R C$ is a dummy that takes the value one if municipality $m$ experiences a violent event by FARC between 2011 and 2012. Negotiation is a dummy that takes the value from 2013 on wards. The set of baseline controls include the total population, a coca suitability index, a rurality index, and a poverty index. All of them interacted with year fixed effects. Robust standard errors are clustered at the municipality level presented in parenthesis. We also present p-values that control for the family-wise error rate in multiple hypotheses testing following Jones et al. (2019) and Westfall and Young (1993). * is significant at the $10 \%$ level, $* *$ is significant at the $5 \%$ level, $* * *$ is significant at the $1 \%$ level. 


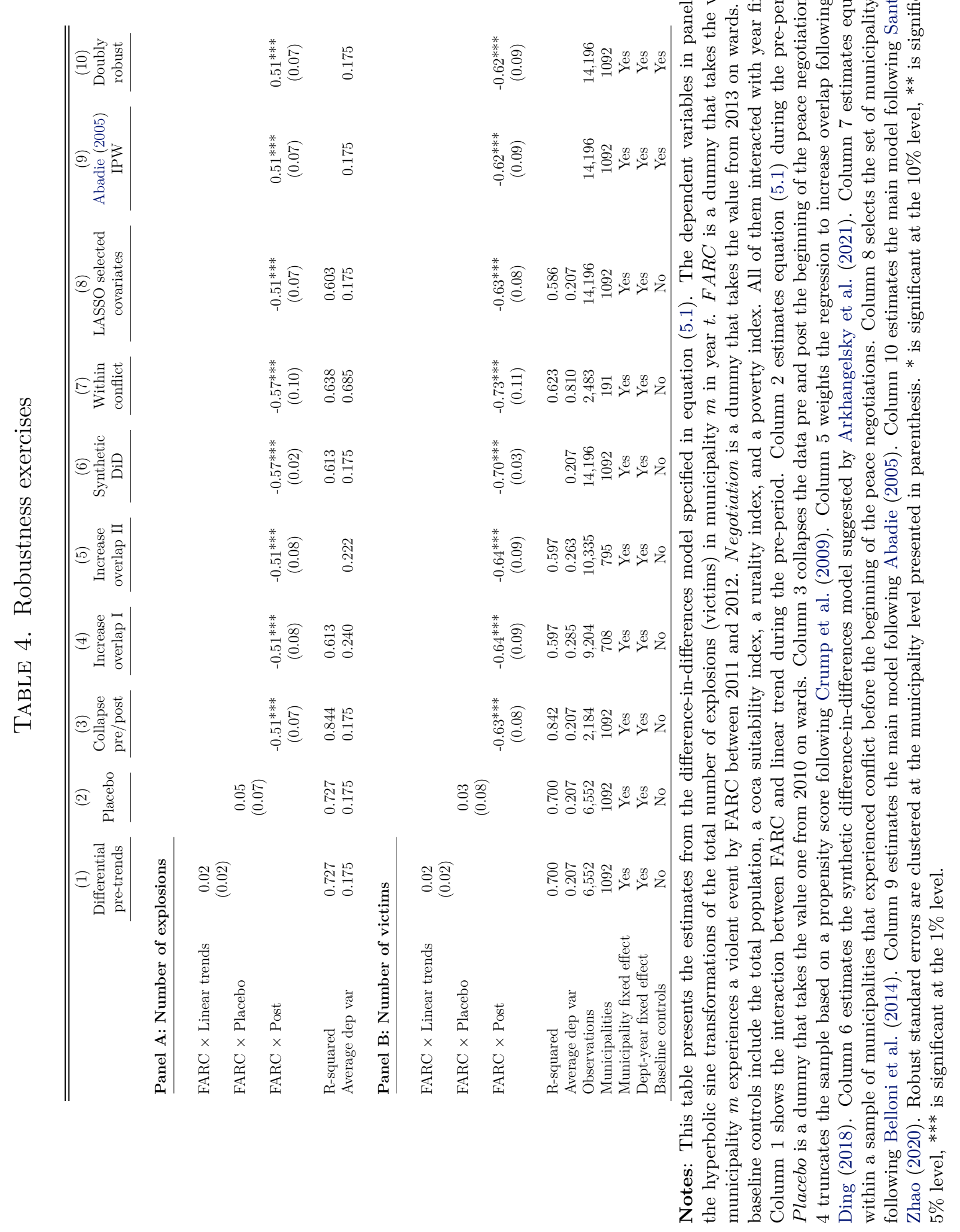




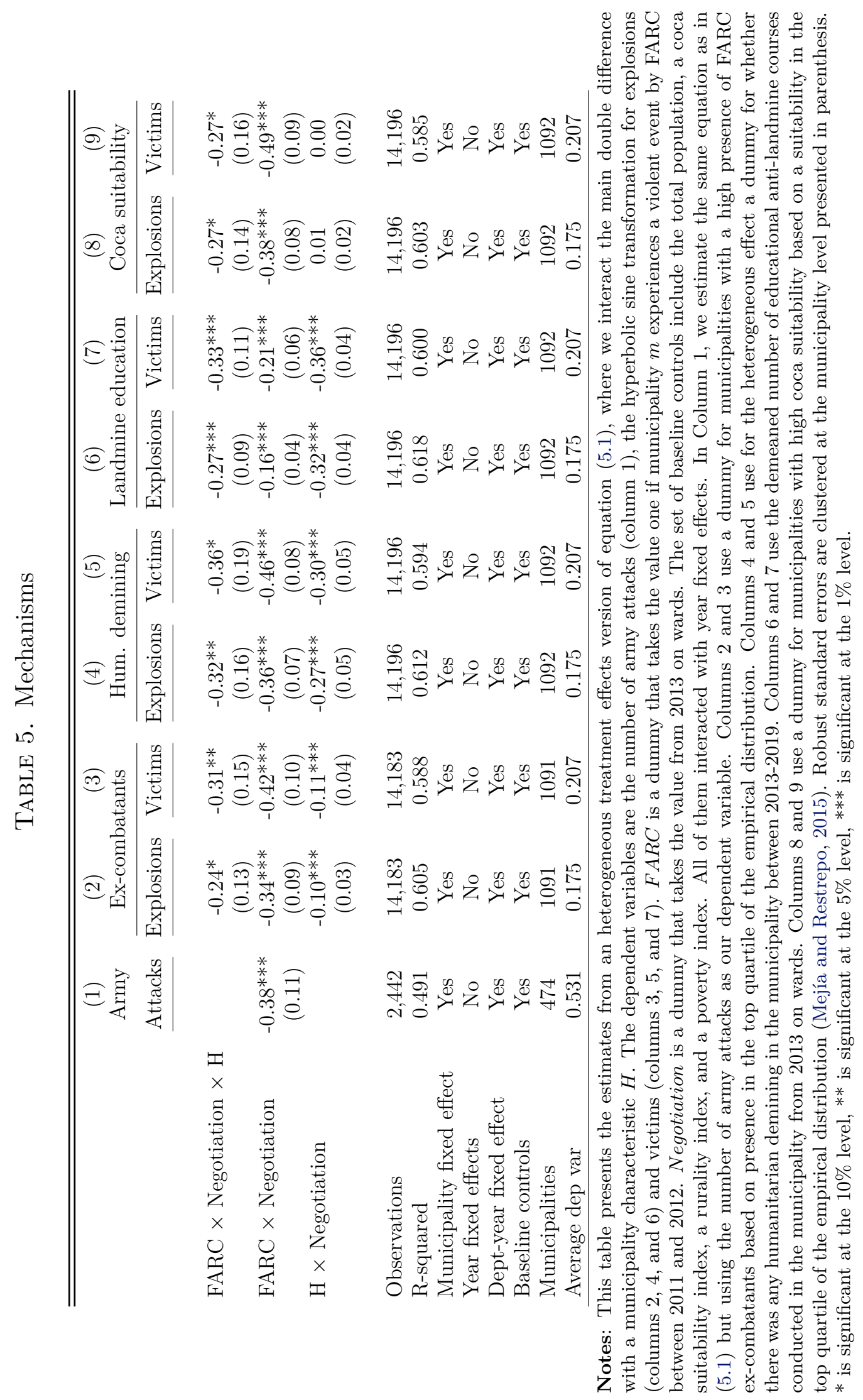




\title{
ONLINE APPENDIX (not for publication) How Peace Saves Lives: Evidence from Colombia
}

\author{
by Sergio Perilla, Mounu Prem, Miguel Purroy, and Juan F. Vargas
}

\section{ApPendix A1. DATA DESCRIPTION AND SOURCES}

A1.1. Additional variables. To test potential mechanisms, we exploit cross-sectional variation across municipalities in terms of i) the presence of FARC ex-combatants, ii) the incidence of humanitarian demining, iii) landmines education programs, and iv) the suitability to grow illegal coca crops. We construct the first measure using a detailed registry of demobilized people in Colombia provided by the Agency for Reincorporation and Normalization. The source identifies the municipality of residence of each ex-combatant and the armed group that they demobilized from.

The second measure is a dummy that identifies municipalities in which local and international NGOs have conducted humanitarian demining operations since 2013. While humanitarian demining first took place in 2004 to remove the landmines that the military had planted in the 1980s to protect their basis, the intensity of the ongoing conflict hindered the expansion of these efforts until the start of the peace negotiations with the FARC in $2013 .^{35}$

The third measure identifies the total number of mine risk education programs implemented in each municipality. Those programs aim to increase capabilities among civilians in landmine-affected areas to prevent future landmine accidents. In Colombia, the Integral Action Against Mines office designed, supervised, and keep detail registry of all the mine education risk programs implemented in the country.

The fourth one is a suitability index to grow coca, the main input in the production of

\footnotetext{
${ }^{35}$ Prem et al. $(2022 \mathrm{a})$ provide a comprehensive review of humanitarian demining in Colombia.
} 
cocaine, of which Colombia is the main exporter. This index was built by Mejía and Restrepo (2015) based on predicted crop yields using exogenous municipal geographic and weather characteristics. ${ }^{36}$

Finally, we also add municipality characteristics as baseline controls. These include total population, a rurality index, and a poverty index, from the CEDE municipal panel compiled by Acevedo et al. (2014).

\section{Appendix A2. AdDitional AnAlysis}

A2.1. Identifying assumption. To complement the tests reported in the main text regarding the validity of the main identifying assumption, here we also check for pre-testing bias and bias from a pre-peace negotiation linear trend following Roth (2021), and estimate confidence sets for our parameter of interest that allow for deviations of the parallel trend assumption following Rambachan and Roth (2021). As for the former, we first estimate the trend that has a $50 \%$ chance of passing the pre-test. For both outcomes, we find a positive and small trend. Figure A5 in the Appendix shows the estimated nonparametric regression adding both the trend that has a $50 \%$ power of being detected given the precision of the estimates in the pre-period, and the trend corrected for pre-testing bias. We find that the unconditional bias is below $25 \%$ for both outcomes, while the conditional one is below 31\% (see Appendix Table A3 for the computed slope and the size of the biases).

Regarding the latter, we estimate confidence sets for our parameter of interest that allow for deviations of the parallel trend assumption following Rambachan and Roth (2021).

\footnotetext{
${ }^{36}$ The observed coca crop yields are obtained from several rounds of a nationally representative household survey of coca farmers that was conducted between 2005 and 2010 by the United Nations Office on Drugs and Crime (UNODC). Surveyed coca growers were randomly selected using the satellite estimates of coca production. In total, 1,678 farmers were surveyed in 64 municipalities scattered around the country. The characteristics used to predict coca yields ate the average municipal altitude, a soil erosion index, a soil aptitude index based on soil nutrients, minerals, average rainfall levels, and the topography of the municipality.
} 
We use the size of the trend that has a $50 \%$ power of being detected given the precision of the estimates in the pre-period as the maximum change in the trend during consecutive periods, $M$ (Roth, 2021). We start by allowing for a linear deviation of the parallel trend assumption $(M=0)$. For both outcomes, we find that the confidence sets are negative, do not include zero, and are of a similar magnitude to the baseline estimate (see Appendix Figure A6). When we allow for non-linear deviations, i.e., the trend can change size and sign for consecutive periods $(M>0)$, we find that for the average treatment effect related to landmine explosions (victims) the confidence sets do not include the zero for the case of violations of up to $50 \%(60 \%)$ of the maximum value of $M$ (see Panels A and $\mathrm{C}$ of Figure A6 of the Appendix). We find a similar result if we create the confidence set for the coefficient in 2017, i.e., the first year after the signing of the peace agreement (see Panels B and D).

A2.1.1. Alternative outcome and treatment measurements. Our main specification uses as a dependent variable the hyperbolic sine transformation of landmine explosions and victims. Our results are robust to parametrizing differently the dependent variable. Columns 1 to 3 of Appendix Table A4 re-estimate the baseline model with the dependent variable defined in levels, with a dummy that captures the extensive margin of landmine explosions or victims, and with the number of events normalized by 10,000 inhabitants. In all cases, we find large, negative, and statistically significant effects. ${ }^{37}$

Likewise, they are robust to using other definitions of our cross-section treatment dimension, namely a dummy for the exposure to any FARC violence prior to the beginning of the peace negotiations. The first definition, used in Column 4, defines the treatment over the same time frame (2011-2012) but divides the number of FARC attacks over the

\footnotetext{
${ }^{37}$ Appendix Tables A5 and A6 present the same exercise for the different sets of victims. The results are
} robust to the dependent variable definition. 
municipal population and standardizes the result. As such, this measure takes into account the intensity of FARC violence. The other two definitions extend the time period over which the extensive margin exposure to FARC is defined, one starting in 2003 (the start of Alvaro Uribe's first presidential term), and the other one in 2007 (the start of his second term). See Columns 5 and 6 respectively.

A2.1.2. Influential observations. Finally, we check whether our results come from any particular department, treated municipality, or control. In Panels A and B of Appendix Figure A7, we report the estimates that result from excluding one department at a time. In Panels C and D, we exclude one FARC-affected municipality at the time. Finally, in Panels E and F, we exclude a random 5\% of the control municipalities, and repeat this 100 times. Overall, we find that our estimates are stable to accounting for potential influential observations. 
Appendix A3. AdDitional figures And tables 


\title{
Figure A1. Plan "Renacer" by FARC
}

\author{
Camaradas del Secretariado. Mi saludo
}

1. Impartante las relaciones del camarada TIMO. Con los amigos colaboradores del presidente CHAVEZ. Vale la pena darles a conocer el plan estratégico, asi como se le presento a su jefe, a su asesor y amigo CHACIN. igual de importante reforzar en los encuentros con los ELENOS propiciados por el gobierno, la necesidad de crear la fusión en algunas regiones de domino primordial de las FARC EP y buscar el apoyo de los asistentes a estas reuniones. A la senadora PIEDAD, hablarte sobre la necesidad de crear un partido del pueblo y buscar su alianza al movimiento Bolivariano.

2. Ya todos conocemos los cambios en la situación política del pais y al mismo tiempo la situación interna de nuestra organización guerrillera, por eso es tiempo de realizar algunos cambios temporales y pasar nuevamente a la táctica de GUERRA DE GUERRILLAS, plan propuesto como "RENACER REVOLUCIONARIO DE LAS MASAS" es alli donde se encuentra la estrategia y el éxito de la guerra de guerrillas con el desarrollo del PLAN PATRIOTA y la mal llamada POLITICA DE SEGURIDAD DEMOCRATICA, el enemigo ha ganado espacio geográfico y por mal utilización de nuestros recursos sociales también hemos visto afectado el espacio político social. Situación un poco distinta a la manejada por el camarada SANTRICH y MATIAS con las células del cauca, Valle y Nariño, estructuras que dejaron fortalecidas antes de trasladarse al área dei Bloque Caribe. Por esto dentro del desarrolto de este plan propongo adelantar aigunas actividades y otras ponerlas en consideración para su posterior ejecución.

3. Desarrollar por to menos, antes de terminar el presente año, cursos de misiones especiales, programa desarrollado por el Comando Conjunto Central y que ha dado resultados positivos en corto tiempo luego de terminar el entrenamiento de las unidades.

4. Disponer de 5 á 6 millones de dólares del fondo del Secretariado, para adquirir intendencia, material de guerra y comunicaciones. Necesario para fortalecer la capacidad de lucha de los guerrilleros urbanos y milicias. Del manejo de este dinero se encargara el Bloque Oriental y cada bloque aportara entre 1 y 2 millones según condiciones para este fin.

5. Aumentar los visos defensivos y de movilidad con minados para detener el avance de las operaciones enemigas, ya conocemos que las minas son el único factor que los detiene y los intimida, por esto aumentar los cursos de explosivistas para lograr un nivel de conocimiento en explosivos, generalizados dentro de la guerrillerada e iniciar igualmente el entrenarniento del personal del MB y de milicias, haciendo énfasis en que no se debe de manipular los mismos con excesiva confianza los que lleva a accidentes.

6. El Comando Conjunto ya con capacidades en este ámbito, ejecutara algunas operaciones, para mantener el nombre de nuestra organización y evitar asi crear un ambiente de derrota progresiva a las FARC EP.

7. En la medida que se vayan ejecutando los entrenamientos, como ejercicios finales se deben de colocar objetivos reales, que propicien golpes al enemigo.

8. Con el uso de minas y explosivos se equilibran las cargas frente a un enemigo numeroso, bastante equipado y con gran poder de fuego.

9. Los resultados logrados en el Guayabero, son una muestra de la necesidad de entrenar bien militarmente a las milicias y miembros del MB, aun cuando se trata de un poder invaluable y necesario, solo se encuentran proporcionando inteligencia y logistica, situación que se dificulta cuando hay controles enemigos sobre las rutas o medios, situación presentada con Cesar. Hay que pensar en un mecanismo para reforzar ese mismo mecanismo sin exponer la seguridad y brindar más resultados al enemigo.

10. Es dificil para el enemigo mantener el despliegue de personal, material sobre un área permanente, por esto que al retomar la táctica de guerrilias móviles aunado con los golpes que pueden propinar las milicias y el MB. fortalecerá la presencia nuestra en áreas.

11. La táctica de francotiradores ya tratada desde la Octava Conferencia, se debe desarrollar con los recursos destinados dentro de la ejecución de este plan, adquinir el material necesario, fusiles y munición especializada por Bloque, el efecto de la ejecución de esta maniobra tendrá iguales resultados que los minados.

12. Los grupos encargados de la tarea telefónica se debe incrementar en todas las áreas de operaciones enemigas, está comprobado que estando lo bastando cerca de ellos arroja buenos resultados para IC.

13. Alistar por bloque unidades de confianza y que tengan el servicio militar para que se presenten como soldados profesionales y utilizarlos para IC. Como se esta trabajando en el Oriental y el Bloque Sur.

14. En la historia de las guerras de guerrillas, se ha demostrado que lo que ha creado un paralelo de negociación obligatorio entre la parte más fuerte y el apoyo aéreo, que termina por causar gran daño a la contraparte, pero también es claro que si se logra golpear este paral, los resultados en la balanza se inclinan a favor, es por esto que se hace de extrema necesidad lograr la negociación de misiles que nos permitan propinar golpes contundentes al poderío aéreo del enemigo. Las tareas de destrucción de aeronaves mediante la infiltración como to ha hecho el Oriental nos ha demostrado que el precio es alto y
se cometen errores.

Es todo y espero sus opiniones. Alfonso 
Figure A2. Change in conflict since peace-negotiation

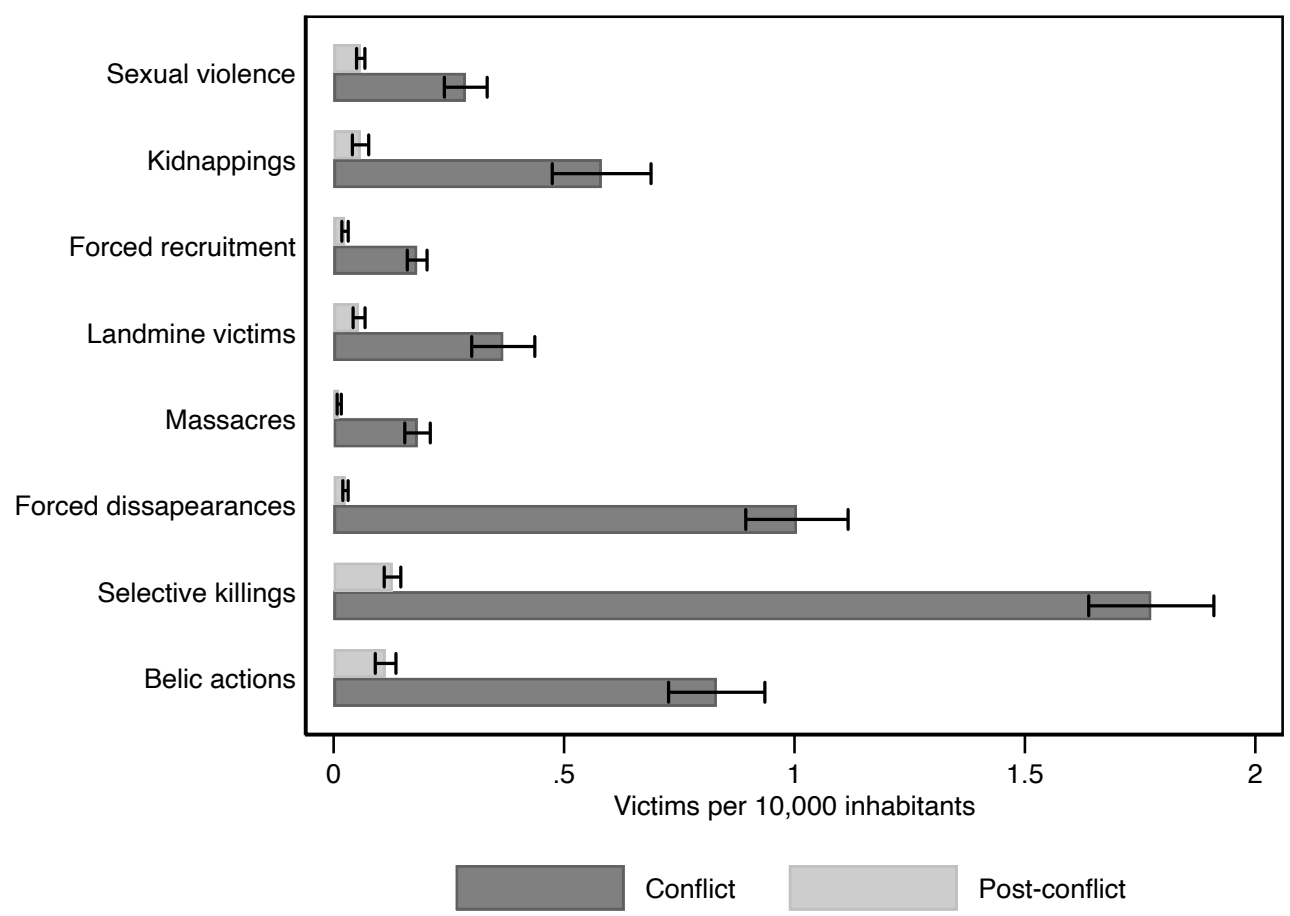

Notes: This figure presents the average incidence of conflict for different measures. We present the average across municipalities for the years between 2002 and 2012 (conflict) and between 2013 and 2019 (post-conflict). We present confidence intervals at the $95 \%$. 
Figure A3. Landmine FARC explosions and victims

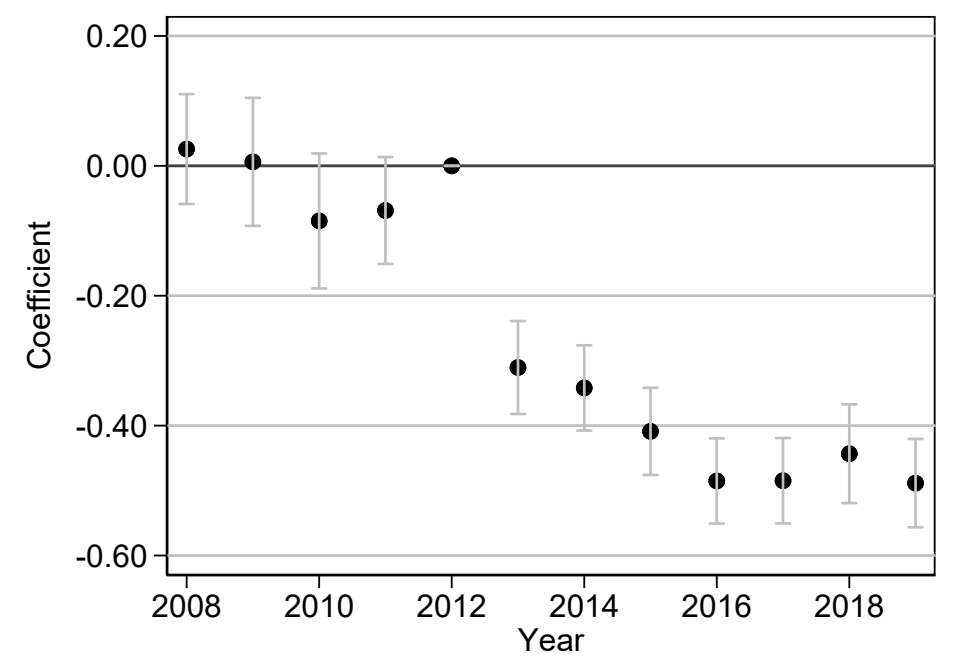

A. Victims

Notes: This figure presents the estimates from the dynamic difference-in-differences model at the grid level. We divide the country into grids of $10 x 10 \mathrm{~km}$ and count the number of victims in each year. The FARC treatment dummy is defined based on the presence of an explosion in that grid between 2007 and 2012 that was associated with FARC.The dependent variable is the hyperbolic sine transformation for our measure of landmine victims. The specification includes municipality-year and grid-level fixed effects. We present the point estimates as well as the $95 \%$ confidence interval. 


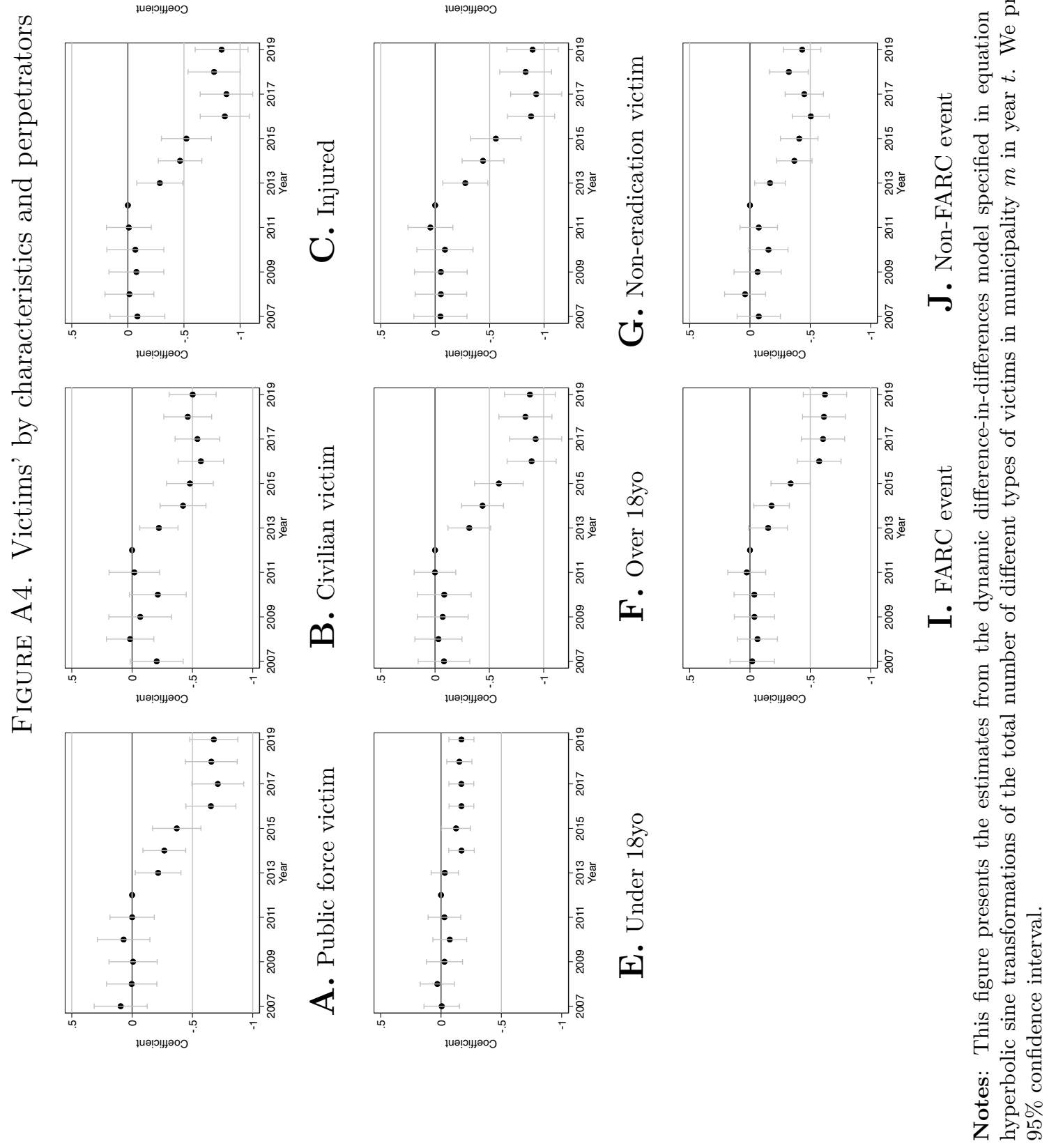


FiguRE A5. Hypothesized pre-trends

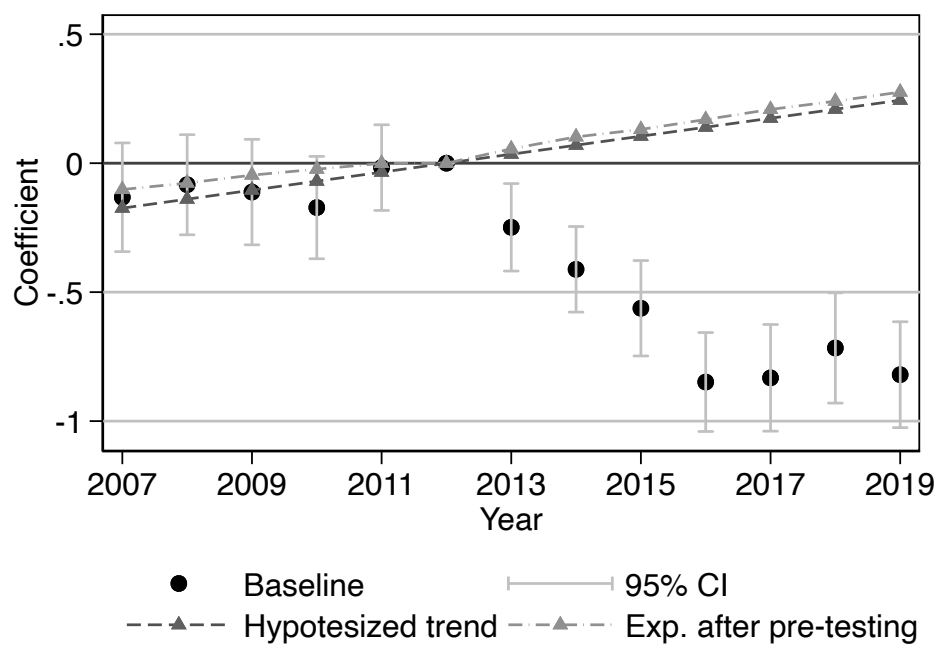

A. Explosion

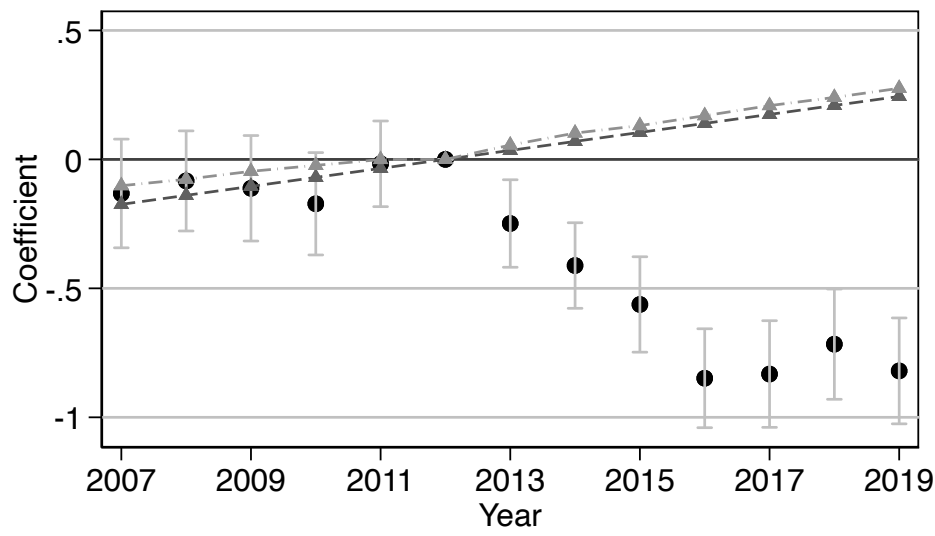

- Baseline $\longmapsto 95 \% \mathrm{Cl}$

---- Hypotesized trend $-\cdot-\ldots$ Exp. after pre-testing

B. Victims

Notes: This figure presents the estimates from the dynamic difference-in-differences model specified in equation (5.3). The dependent variable in panel A (B) is the hyperbolic sine transformations of the total number of explosions (victims) in municipality $m$ in year $t$. We present the point estimates as well as the $95 \%$ confidence interval. We also present the trend that has a $50 \%$ chance of being detected in the pre-period and the trend corrected for pre-testing bias (Roth, 2021). 
FIgURE A6. Violations to the parallel trend assumption

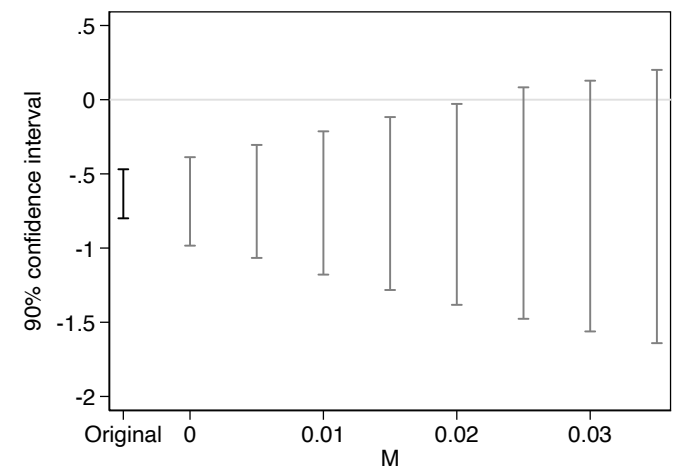

A. Explosions: Average

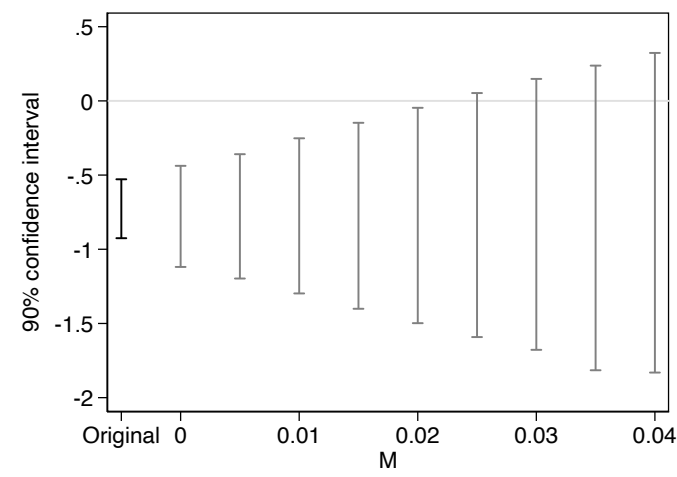

C. Victims: Average

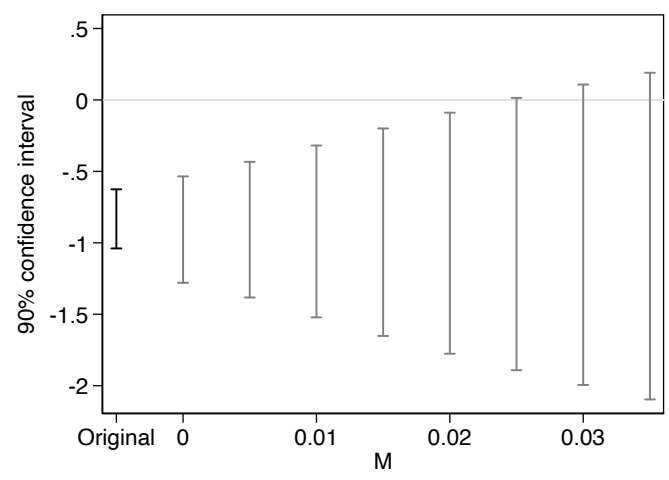

B. Explosions: Year 2017

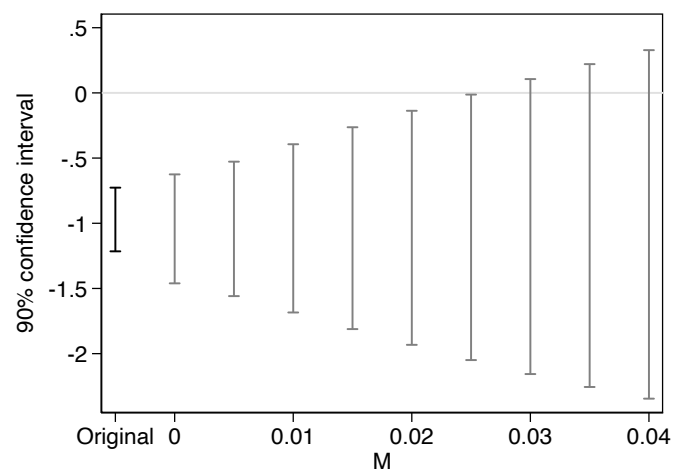

D. Victims: Year 2017

Notes: This figure presents the confidence set at $90 \%$ for linear and non-linear violation of the parallel trends assumption (Rambachan and Roth, 2021). The dependent variable is the hyperbolic sine transformations of the total number of explosions (panels A and B) and victims (panels C and D). $M$ measures the size of the change in the trend between consecutive periods. Thus, $M=0$ is a linear violation of the parallel trend assumption. The maximum value of $M$ is equal to the trend that has a $50 \%$ power of being detected given the precision of the estimates in the pre-period (Roth, 2021). Panels A and B allow for non-linear violations of any sign, while panels $\mathrm{C}$ and $\mathrm{D}$ for increasing violations. 
FiguRE A7. Robustness to influential observations: Departments, FARC municipalities, and controls

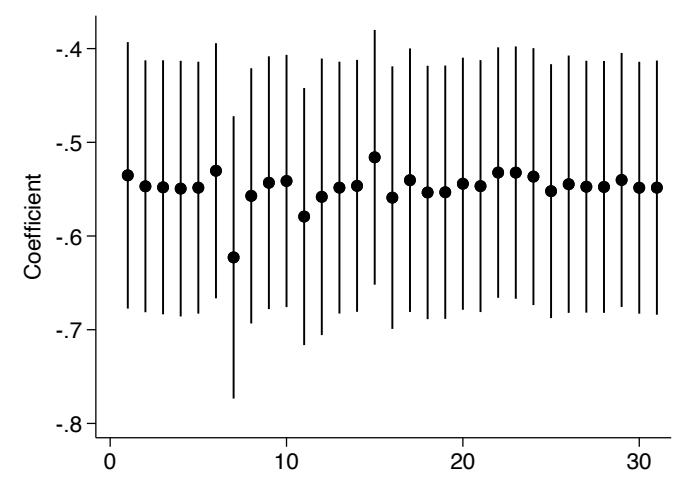

A. Excl. Dept: Explosions

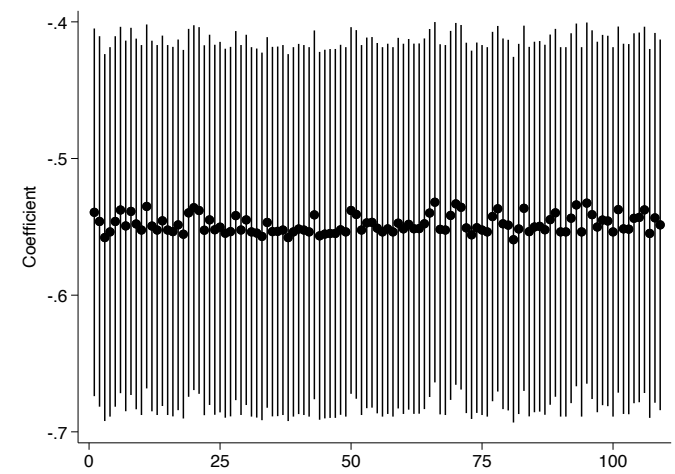

C. Excl. FARC Mun: Explosions

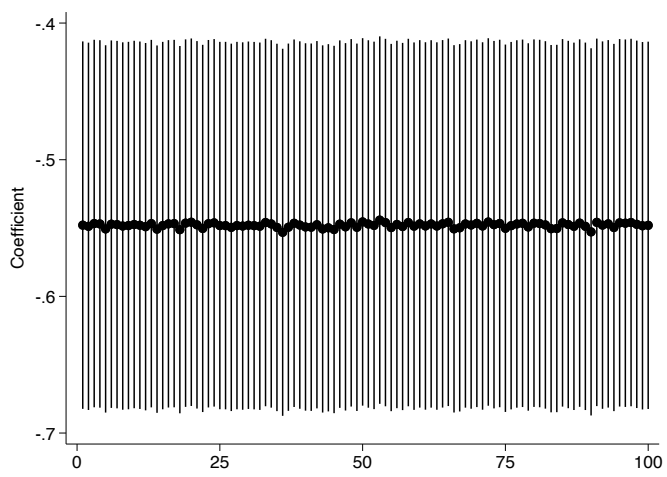

E. Excl. $5 \%$ controls: Explosions

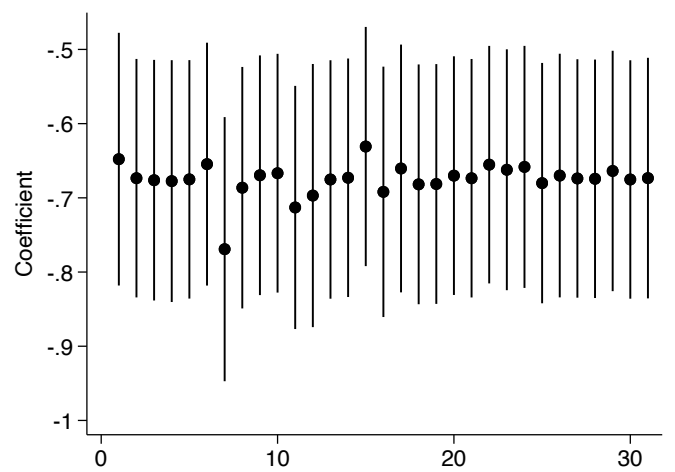

B. Excl. Dept: Victims

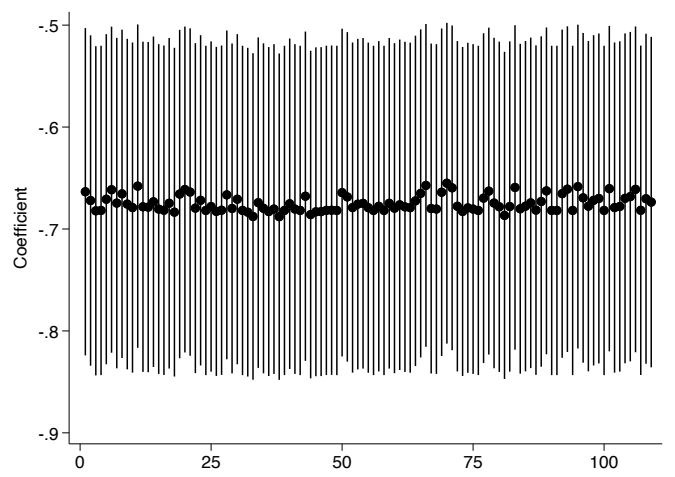

D. Excl. FARC Mun: Victims

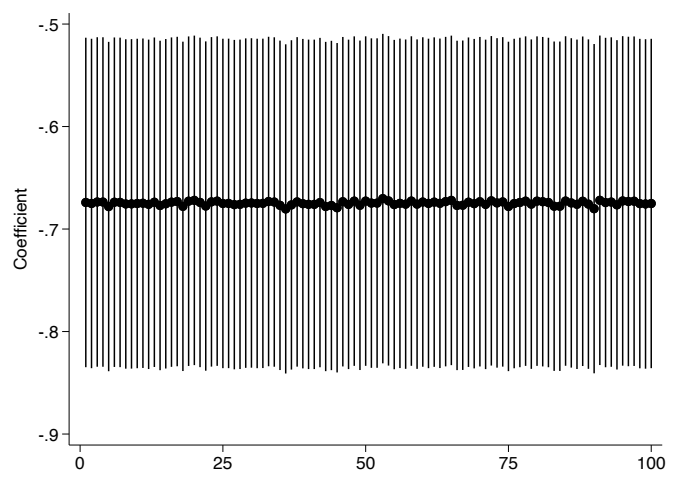

F. Excl. 5\% controls: Victims

Notes: This figure presents the results from the difference-in-differences specification from equation (5.1), but excluding one department at the time (panels A and B), excluding one treated unit at the time (panels C and D), and excluding a random set of $5 \%$ of control municipalities a 100 times (panels $\mathrm{E}$ and F). We present the point estimate and the confidence interval at the $95 \%$ level. 


\section{Figure A8. Distribution of placebo treatments}

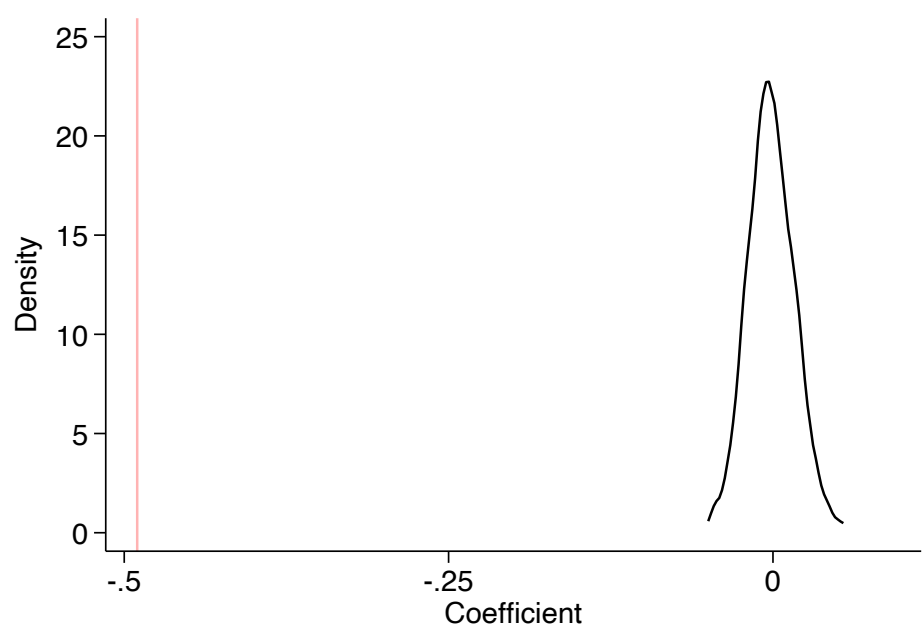

kernel $=$ epanechnikov, bandwidth $=0.0054$

A. Explosions

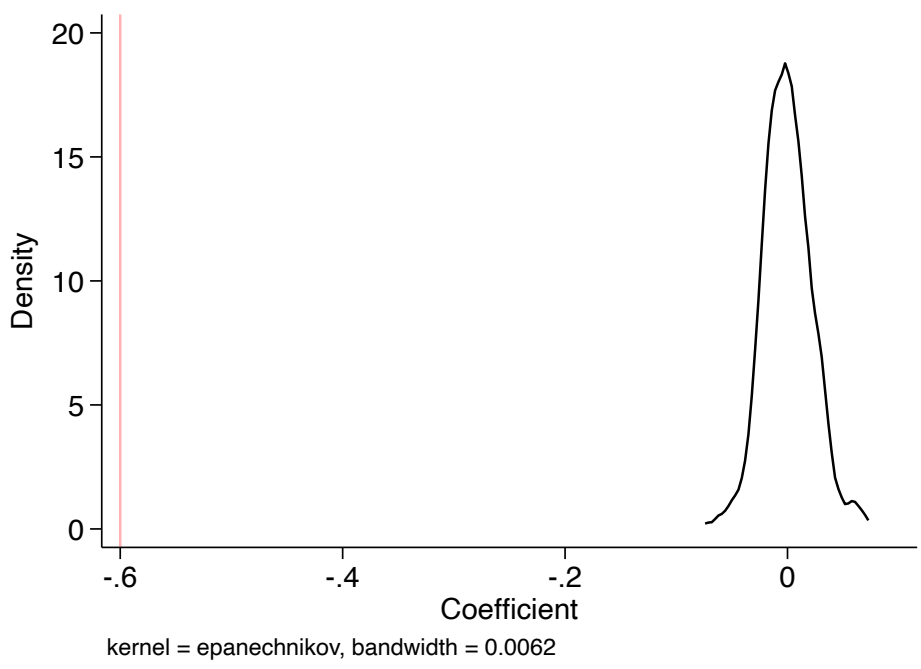

B. Victims

Notes: This figure presents the distribution of placebo treatments where we randomize the assignment of a municipality to have FARC presence before the ceasefire based on the number of municipalities exposed to FARC violence (109). We run the regressions using the main specification from columns 3 and 6 of Table 1 and in the red line we present the coefficient. In all cases the p-value, i.e. the number of cases where the placebo effect shows a larger effect after the ceasefire, is smaller than 0.01 . 
Figure A9. Synthetic difference-in-differences

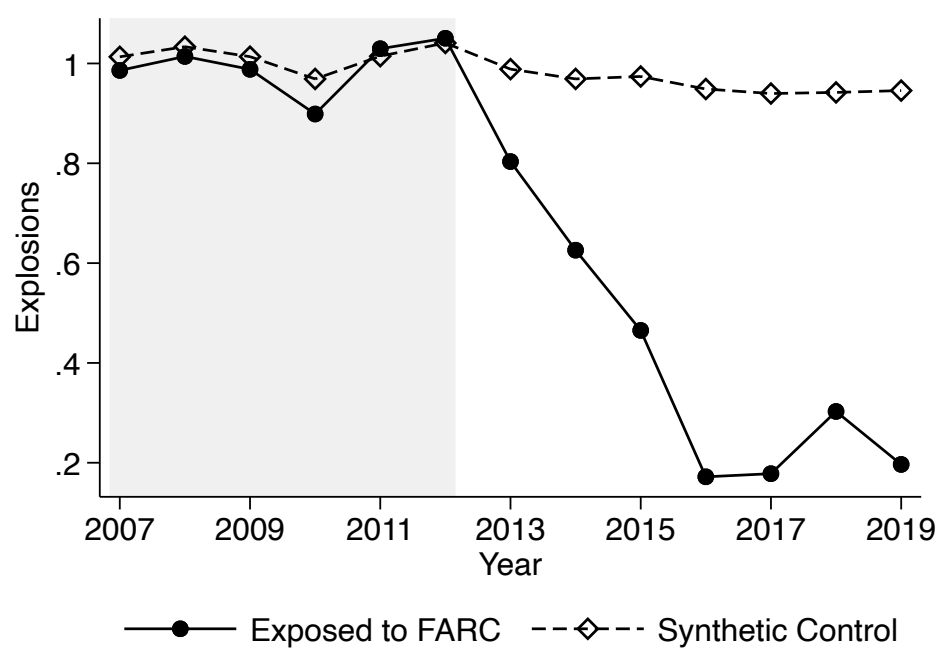

A. Explosion

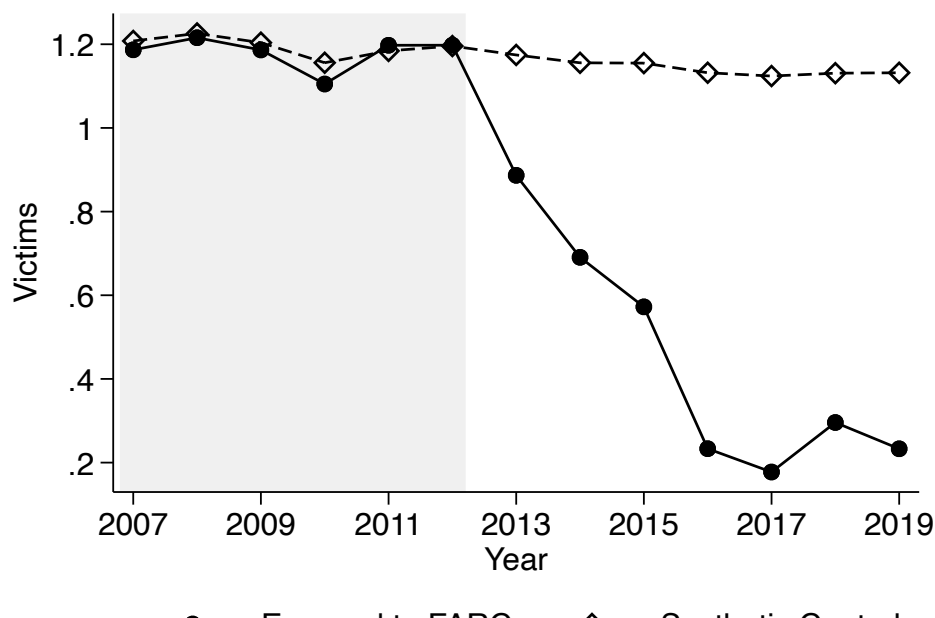

B. Victims

Notes: In this figure, we estimate a synthetic difference-in-differences model following Arkhangelsky et al. (2021). 
Figure A10. The effect of the peace negotiation on homicides

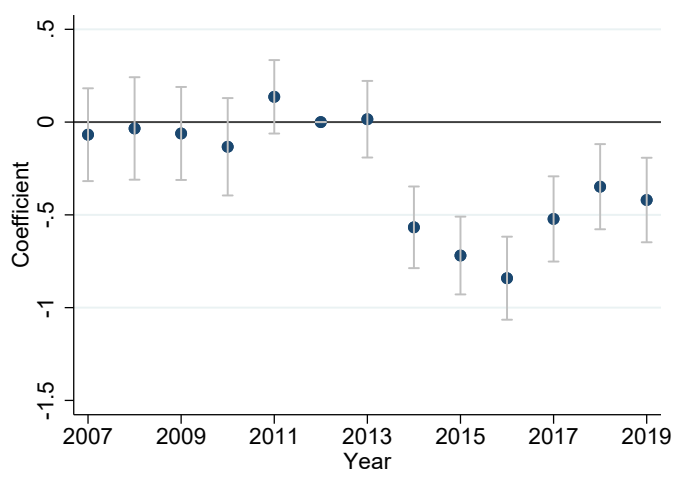

A. Explosion

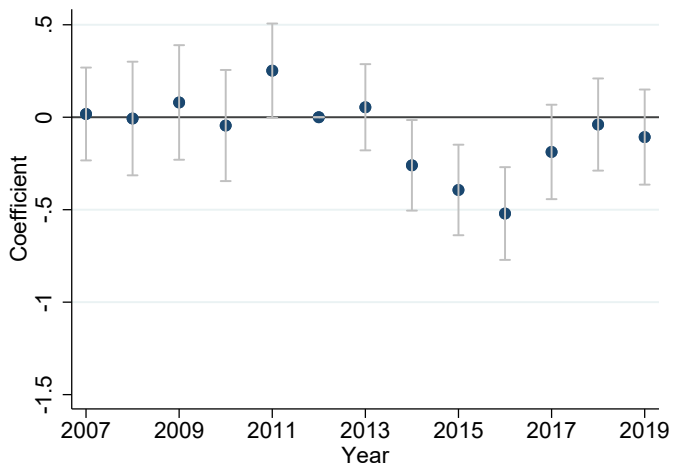

B. Explosion: Adds dep-year FE

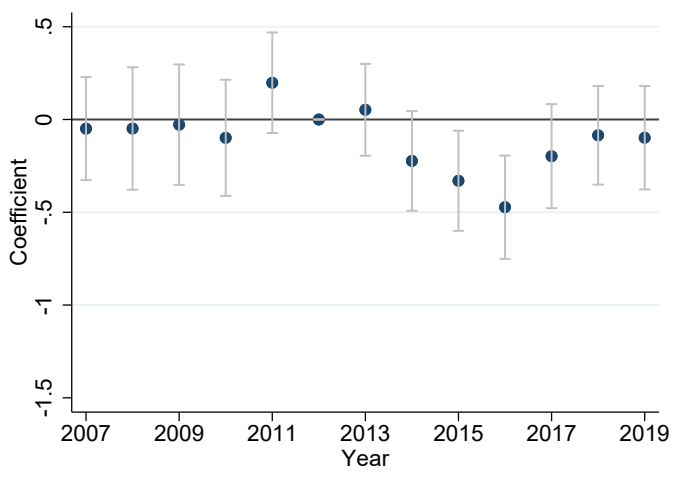

C. Explosion: Baseline controls

Notes: This figure presents the estimates from the dynamic difference-in-differences model specified in equation (5.3). The dependent variable is the hyperbolic sine transformations of the number of homicides in municipality $m$ in year $t$. The set of baseline controls include the total population, a coca suitability index, a rurality index, and a poverty index. All of them interacted with year fixed effects. We present the point estimates as well as the 95\% confidence interval. 
TABle A1. Summary statistics

\begin{tabular}{|c|c|c|}
\hline & $\begin{array}{c}\text { (1) } \\
\text { Average }\end{array}$ & $\begin{array}{c}(2) \\
\text { Standard } \\
\text { deviation }\end{array}$ \\
\hline Explosions & 0.407 & 1.931 \\
\hline Victims & 0.656 & 3.406 \\
\hline \multicolumn{3}{|l|}{ Victim's type: } \\
\hline Public force & 0.409 & 2.276 \\
\hline Civilian & 0.248 & 1.743 \\
\hline Injured & 0.543 & 2.919 \\
\hline Dead & 0.113 & 0.780 \\
\hline Under 18 years old & 0.048 & 0.427 \\
\hline Over 18 years old & 0.608 & 3.175 \\
\hline No eradication & 0.609 & 3.186 \\
\hline In eradication & 0.047 & 0.672 \\
\hline Related to FARC & 0.207 & 1.193 \\
\hline Non-related to FARC & 0.200 & 1.050 \\
\hline Exposed to FARC violence & 0.100 & 0.300 \\
\hline Population & $20,883.2$ & $26,088.3$ \\
\hline Share of rural population & 0.587 & 0.233 \\
\hline
\end{tabular}

Notes: This table presents the summary statistics for our main outcomes before 2013, exposure to FARC violence, and other municipality outcomes. 
TABLE A2. Differences by exposure to FARC violence

\begin{tabular}{|c|c|c|c|}
\hline & $\begin{array}{c}(1) \\
\text { Treated }\end{array}$ & $\begin{array}{c}(2) \\
\text { Control }\end{array}$ & $\begin{array}{c}(3) \\
\text { Average } \\
\text { difference }\end{array}$ \\
\hline Explosions & $\begin{array}{c}2.601 \\
(3.625)\end{array}$ & $\begin{array}{c}0.164 \\
(0.897)\end{array}$ & $\begin{array}{c}2.437^{* * * *} \\
(0.347)\end{array}$ \\
\hline Victims & $\begin{array}{c}4.321 \\
(6.140)\end{array}$ & $\begin{array}{c}0.250 \\
(1.364)\end{array}$ & $\begin{array}{c}4.071^{* * *} \\
(0.588)\end{array}$ \\
\hline Victim's type: & & & \\
\hline Public force & $\begin{array}{c}2.713 \\
(4.023)\end{array}$ & $\begin{array}{c}0.153 \\
(0.855)\end{array}$ & $\begin{array}{c}2.559^{* * *} \\
(0.385)\end{array}$ \\
\hline Civilian & $\begin{array}{c}1.609 \\
(2.807)\end{array}$ & $\begin{array}{c}0.097 \\
(0.633)\end{array}$ & $\begin{array}{c}1.512^{* * *} \\
(0.269)\end{array}$ \\
\hline Injured & $\begin{array}{c}3.595 \\
(5.258)\end{array}$ & $\begin{array}{c}0.204 \\
(1.186)\end{array}$ & $\begin{array}{c}3.390 * * * \\
(0.503)\end{array}$ \\
\hline Dead & $\begin{array}{c}0.726 \\
(1.210)\end{array}$ & $\begin{array}{c}0.045 \\
(0.229)\end{array}$ & $\begin{array}{c}0.681^{* * * *} \\
(0.116)\end{array}$ \\
\hline Under 18 years old & $\begin{array}{c}0.320 \\
(0.539)\end{array}$ & $\begin{array}{c}0.018 \\
(0.119)\end{array}$ & $\begin{array}{c}0.302^{* * *} \\
(0.052)\end{array}$ \\
\hline Over 18 years old & $\begin{array}{c}4.002 \\
(5.807)\end{array}$ & $\begin{array}{c}0.232 \\
(1.280)\end{array}$ & $\begin{array}{c}3.770 * * * \\
(0.556)\end{array}$ \\
\hline No eradication & $\begin{array}{c}3.997 \\
(5.755)\end{array}$ & $\begin{array}{c}0.233 \\
(1.245)\end{array}$ & $\begin{array}{c}3.764^{* * *} \\
(0.551)\end{array}$ \\
\hline In eradication & $\begin{array}{c}0.324 \\
(0.939)\end{array}$ & $\begin{array}{c}0.017 \\
(0.212)\end{array}$ & $\begin{array}{c}0.308^{* * *} \\
(0.090)\end{array}$ \\
\hline Related to FARC & $\begin{array}{c}1.437 \\
(2.289)\end{array}$ & $\begin{array}{c}0.071 \\
(0.432)\end{array}$ & $\begin{array}{c}1.366^{* * *} \\
(0.219)\end{array}$ \\
\hline Non-related to FARC & $\begin{array}{c}1.164 \\
(1.745)\end{array}$ & $\begin{array}{c}0.093 \\
(0.550)\end{array}$ & $\begin{array}{c}1.071^{* * *} \\
(0.167)\end{array}$ \\
\hline Population & $\begin{array}{c}29819.267 \\
(28182.511)\end{array}$ & $\begin{array}{c}19892.280 \\
(25681.167)\end{array}$ & $\begin{array}{c}9926.987^{* * *} * \\
(2811.513)\end{array}$ \\
\hline Share of rural population & $\begin{array}{c}0.634 \\
(0.217)\end{array}$ & $\begin{array}{c}0.581 \\
(0.234)\end{array}$ & $\begin{array}{c}0.053^{* *} \\
(0.022)\end{array}$ \\
\hline
\end{tabular}

Notes: This table presents the differences in exposure to landmine victimization before 2013 by exposure to FARC violence. Columns 1 and 2 present the average and standard deviation. Column 3 presents the average difference between treated and control and the standard error. $*$ is significant at the $10 \%$ level, ** is significant at the $5 \%$ level, $* * *$ is significant at the $1 \%$ level. 
TABLE A3. Bias from hypothesized linear pre-trend

\begin{tabular}{|c|c|c|c|c|}
\hline & $\begin{array}{c}(1) \\
\text { Estimate }\end{array}$ & $\begin{array}{c}(2) \\
\text { Slope }\end{array}$ & $\begin{array}{c}(3) \\
\text { Unconditional } \\
\text { bias }\end{array}$ & $\begin{array}{c}(4) \\
\text { Conditional } \\
\text { bias }\end{array}$ \\
\hline Explosions & -0.55 & 0.034 & 0.139 & 0.168 \\
\hline Victims & -0.67 & 0.041 & 0.139 & 0.170 \\
\hline
\end{tabular}

Notes: This table presents the estimated parameter from our baseline specification in Table 1 and the main estimates based on Roth (2021). In column 2, we present the pre-trend that has a $50 \%$ power of being detected given the precision of the estimates in the pre-period. In column 3, we present the average bias suggested by this trend, while in column 4, the bias from the adjusted pre-trend that takes into account the pre-testing bias that arises from the fact that the analysis shown is conditional on passing a pre-test. 
TABLE A4. Robustness exercises II

\begin{tabular}{|c|c|c|c|c|c|c|}
\hline \multirow{4}{*}{\multicolumn{2}{|c|}{ Panel A: Number of explosions }} & $(2)$ & (3) & (4) & $(5)$ & (6) \\
\hline & & \multicolumn{2}{|c|}{ tcome measurement } & \multicolumn{3}{|c|}{ FARC measures: } \\
\hline & & Dummy & $\begin{array}{c}\text { Over } \\
\text { population }\end{array}$ & \multirow[t]{2}{*}{$\begin{array}{c}\text { FARC cases } \\
\text { over population }\end{array}$} & \multirow[t]{2}{*}{$\begin{array}{c}\text { FARC } \\
\text { since } 2003\end{array}$} & \multirow[t]{2}{*}{$\begin{array}{c}\text { FARC } \\
\text { since } 2007\end{array}$} \\
\hline & & & & & & \\
\hline FARC $\times$ Negotiation & $\begin{array}{c}-1.53^{* * *} \\
(0.27)\end{array}$ & $\begin{array}{c}-0.18^{* * *} \\
(0.03)\end{array}$ & $\begin{array}{c}-0.62^{* * *} \\
(0.13)\end{array}$ & $\begin{array}{c}-0.15^{* * *} \\
(0.04)\end{array}$ & $\begin{array}{c}-0.15^{* * *} \\
(0.02)\end{array}$ & $\begin{array}{c}-0.25^{* * *} \\
(0.03)\end{array}$ \\
\hline R-squared & 0.533 & 0.506 & 0.443 & 0.595 & 0.589 & 0.595 \\
\hline Average dep var & 0.407 & 0.106 & 0.203 & 0.175 & 0.175 & 0.175 \\
\hline \multicolumn{7}{|c|}{ Panel B: Number of victims } \\
\hline FARC $\times$ Negotiation & $\begin{array}{c}-2.75 * * * \\
(0.48)\end{array}$ & $\begin{array}{c}-0.18^{* * *} \\
(0.03)\end{array}$ & $\begin{array}{c}-1.16^{* * *} \\
(0.22)\end{array}$ & $\begin{array}{c}-0.19^{* * *} \\
(0.05)\end{array}$ & $\begin{array}{c}-0.18^{* * *} \\
(0.02)\end{array}$ & $\begin{array}{c}-0.31^{* * *} \\
(0.03)\end{array}$ \\
\hline R-squared & 0.471 & 0.515 & 0.390 & 0.577 & 0.569 & 0.577 \\
\hline Average dep var & 0.656 & 0.105 & 0.320 & 0.207 & 0.207 & 0.207 \\
\hline Observations & 14,196 & 14,196 & 14,196 & 14,196 & 14,196 & 14,196 \\
\hline Municipalities & 1092 & 1092 & 1092 & 1092 & 1092 & 1092 \\
\hline Municipality fixed effect & Yes & Yes & Yes & Yes & Yes & Yes \\
\hline Dept-year fixed effect & Yes & Yes & Yes & Yes & Yes & Yes \\
\hline Baseline controls & Yes & Yes & Yes & Yes & Yes & Yes \\
\hline
\end{tabular}

Notes: This table presents the estimates from the difference-in-differences model specified in equation (5.1). The dependent variables in panel A (B) are the hyperbolic sine transformations of the total number of explosions (victims) in municipality $m$ in year $t . F A R C$ is a dummy that takes the value one if municipality $m$ experiences a violent event by FARC between 2011 and 2012. Negotiation is a dummy that takes the value from 2013 on wards. The set of baseline controls include the total population, a coca suitability index, a rurality index, and a poverty index. All of them interacted with year fixed effects. Columns 1 to 3 estimates equation (5.1) with the dependent variable in levels, a dummy for at least one event, and the level over 10,000 inhabitants. Columns 4 to 6 change FARC for number of violent events over 10,000 inhabitants, a dummy for at least one event since 2003, and a dummy for at least one violent event since 2007. Robust standard errors are clustered at the municipality level presented in parenthesis. ${ }^{*}$ is significant at the $10 \%$ level, $* *$ is significant at the $5 \%$ level, *** is significant at the $1 \%$ level. 
TABlE A5. Type of landmine victims, FARC, and peace negotiations: Other definitions

\begin{tabular}{|c|c|c|c|c|c|c|}
\hline & $\begin{array}{c}(1) \\
\text { Public } \\
\text { force }\end{array}$ & $\begin{array}{c}(2) \\
\text { Civilian }\end{array}$ & $\begin{array}{c}(3) \\
\text { Injured }\end{array}$ & $\begin{array}{c}(4) \\
\text { Dead }\end{array}$ & $\begin{array}{c}(5) \\
\text { Under } 18 \\
\text { years old }\end{array}$ & $\begin{array}{c}(6) \\
\text { Over } 18 \\
\text { years old }\end{array}$ \\
\hline \multicolumn{7}{|l|}{ Panel A: Dummy } \\
\hline FARC $\times$ Negotiation & $\begin{array}{c}-0.18^{* * *} \\
(0.03)\end{array}$ & $\begin{array}{c}-0.15^{* * *} \\
(0.02)\end{array}$ & $\begin{array}{c}-0.18^{* * *} \\
(0.03)\end{array}$ & $\begin{array}{c}-0.16^{* * *} \\
(0.03)\end{array}$ & $\begin{array}{c}-0.06^{* * *} \\
(0.02)\end{array}$ & $\begin{array}{c}-0.18^{* * *} \\
(0.03)\end{array}$ \\
\hline \multicolumn{7}{|l|}{ Panel B: Levels } \\
\hline FARC $\times$ Negotiation & $\begin{array}{c}-1.77^{* * *} \\
(0.31)\end{array}$ & $\begin{array}{c}-0.97^{* * *} \\
(0.23)\end{array}$ & $\begin{array}{c}-2.28^{* * *} * \\
(0.41)\end{array}$ & $\begin{array}{c}-0.47^{* * *} \\
(0.10)\end{array}$ & $\begin{array}{c}-0.18^{* * *} \\
(0.05)\end{array}$ & $\begin{array}{c}-2.56^{* * *} \\
(0.45)\end{array}$ \\
\hline \multicolumn{7}{|l|}{ Panel C: Over population } \\
\hline FARC $\times$ Negotiation & $\begin{array}{c}-0.74^{* * *} \\
(0.14)\end{array}$ & $\begin{array}{c}-0.42^{* * *} \\
(0.11)\end{array}$ & $\begin{array}{c}-0.96^{* * *} \\
(0.19)\end{array}$ & $\begin{array}{c}-0.20^{* * *} \\
(0.05)\end{array}$ & $\begin{array}{c}-0.06^{*} \\
(0.03)\end{array}$ & $\begin{array}{c}-1.10^{* * *} \\
(0.20)\end{array}$ \\
\hline Observations & 14,196 & 14,196 & 14,196 & 14,196 & 14,196 & 14,196 \\
\hline Municipalities & 1092 & 1092 & 1092 & 1092 & 1092 & 1092 \\
\hline R-squared (Panel A) & 0.496 & 0.410 & 0.502 & 0.370 & 0.258 & 0.515 \\
\hline R-squared (Panel B) & 0.434 & 0.353 & 0.461 & 0.314 & 0.212 & 0.475 \\
\hline R-squared (Panel C) & 0.367 & 0.271 & 0.391 & 0.213 & 0.151 & 0.397 \\
\hline Municipality fixed effect & Yes & Yes & Yes & Yes & Yes & Yes \\
\hline Dept-year fixed effect & Yes & Yes & Yes & Yes & Yes & Yes \\
\hline Baseline controls & Yes & Yes & Yes & Yes & Yes & Yes \\
\hline Average dep var (Panel A) & 0.0769 & 0.0632 & 0.0977 & 0.0470 & 0.0234 & 0.100 \\
\hline Average dep var (Panel B) & 0.409 & 0.248 & 0.543 & 0.113 & 0.0479 & 0.608 \\
\hline Average dep var (Panel C) & 0.206 & 0.114 & 0.268 & 0.0526 & 0.0222 & 0.298 \\
\hline
\end{tabular}

Notes: This table presents the estimates from the difference-in-differences model specified in equation (5.1). The dependent variables are different measure of the types of victims. Panel A presents a dummy for at least one victim, panel $\mathrm{B}$ the number of victims, and panel $\mathrm{C}$ for the number of victims over 10,000 inhabitants. $F A R C$ is a dummy that takes the value one if municipality $m$ experiences a violent event by FARC between 2011 and 2012 . Negotiation is a dummy that takes the value from 2013 on wards. The set of baseline controls include the total population, a coca suitability index, a rurality index, and a poverty index. All of them interacted with year fixed effects. Robust standard errors are clustered at the municipality level presented in parenthesis. ${ }^{*}$ is significant at the $10 \%$ level, $* *$ is significant at the $5 \%$ level, *** is significant at the $1 \%$ level. 
TABLE A6. Type of landmine victims, FARC, and peace negotiations: Other definitions

\begin{tabular}{|c|c|c|c|c|}
\hline & $\begin{array}{c}(1) \\
\text { Non } \\
\text { eradication }\end{array}$ & $\begin{array}{c}(2) \\
\text { In } \\
\text { eradication }\end{array}$ & $\begin{array}{c}(3) \\
\text { Related } \\
\text { to FARC }\end{array}$ & $\begin{array}{c}(4) \\
\text { Non-related } \\
\text { to FARC }\end{array}$ \\
\hline \multicolumn{5}{|l|}{ Panel A: Dummy } \\
\hline FARC $\times$ Negotiation & $\begin{array}{c}-0.18^{* * *} \\
(0.03)\end{array}$ & $\begin{array}{c}-0.04^{* * *} \\
(0.01)\end{array}$ & $\begin{array}{c}-0.18^{* * *} \\
(0.03)\end{array}$ & $\begin{array}{c}-0.16^{* * *} \\
(0.02)\end{array}$ \\
\hline \multicolumn{5}{|l|}{ Panel B: Levels } \\
\hline FARC $\times$ Negotiation & $\begin{array}{c}-2.55^{* * *} \\
(0.45)\end{array}$ & $\begin{array}{c}-0.20^{* *} \\
(0.08)\end{array}$ & $\begin{array}{c}-0.90^{* * *} \\
(0.18)\end{array}$ & $\begin{array}{c}-0.64^{* * *} \\
(0.14)\end{array}$ \\
\hline \multicolumn{5}{|l|}{ Panel C: Over population } \\
\hline FARC $\times$ Negotiation & $\begin{array}{c}-1.06^{* * *} \\
(0.20)\end{array}$ & $\begin{array}{c}-0.10^{* * *} \\
(0.04)\end{array}$ & $\begin{array}{c}-0.34^{* * *} \\
(0.08)\end{array}$ & $\begin{array}{c}-0.29^{* * *} \\
(0.07)\end{array}$ \\
\hline Observations & 14,196 & 14,196 & 14,196 & 14,196 \\
\hline Municipalities & 1092 & 1092 & 1092 & 1092 \\
\hline R-squared (Panel A) & 0.514 & 0.292 & 0.464 & 0.448 \\
\hline R-squared (Panel B) & 0.456 & 0.316 & 0.452 & 0.480 \\
\hline R-squared (Panel C) & 0.380 & 0.210 & 0.407 & 0.350 \\
\hline Municipality fixed effect & Yes & Yes & Yes & Yes \\
\hline Dept-year fixed effect & Yes & Yes & Yes & Yes \\
\hline Baseline controls & Yes & Yes & Yes & Yes \\
\hline Average dep var (Panel A) & 0.104 & 0.008 & 0.067 & 0.077 \\
\hline Average dep var (Panel B) & 0.609 & 0.0473 & 0.207 & 0.200 \\
\hline Average dep var (Panel C) & 0.303 & 0.0170 & 0.101 & 0.102 \\
\hline
\end{tabular}

Notes: This table presents the estimates from the difference-in-differences model specified in equation (5.1). The dependent variables are different measure of the types of victims. Panel A presents a dummy for at least one victim, panel $\mathrm{B}$ the number of victims, and panel $\mathrm{C}$ for the number of victims over 10,000 inhabitants. $F A R C$ is a dummy that takes the value one if municipality $m$ experiences a violent event by FARC between 2011 and 2012 . Negotiation is a dummy that takes the value from 2013 on wards. The set of baseline controls include the total population, a coca suitability index, a rurality index, and a poverty index. All of them interacted with year fixed effects. Robust standard errors are clustered at the municipality level presented in parenthesis. ${ }^{*}$ is significant at the $10 \%$ level, ** is significant at the $5 \%$ level, *** is significant at the $1 \%$ level. 


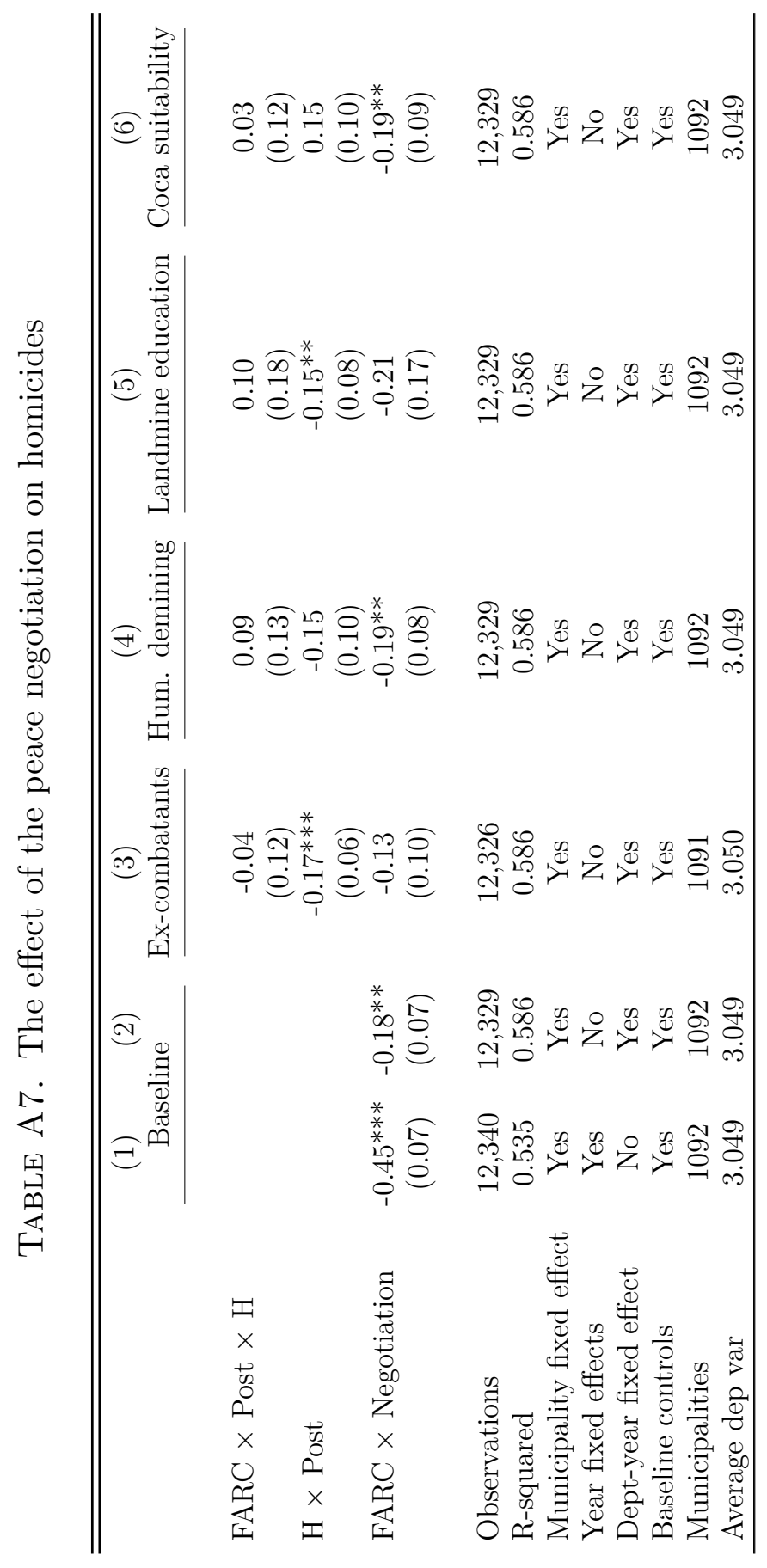

